Mehmet Akif Ersoy Üniversitesi Fen Bilimleri Enstitüsü Dergisi 10(1): 11-27 (2019)

The Journal of Graduate School of Natural and Applied Sciences of Mehmet Akif Ersoy University 10(1): 11-27 (2019)

Araştırma Makalesi / Research Paper

\title{
Çocuk ve Kentsel Mekan İlişkisi: Erzurum'da Çocuk Oyun Alanlarının Erişilebilirlik ve Alansal Yeterlilik Analizi
}

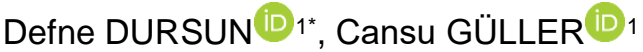 \\ ${ }^{1}$ Atatürk Üniversitesi, Mimarlık ve Tasarım Fakültesi, Erzurum \\ Geliş Tarihi (Received): 20.01.2019, Kabul Tarihi (Accepted): 16.02.2019 \\ $\square$ Sorumlu Yazar (Corresponding author*): defnedursun@gmail.com \\ (C) +904422316151 且 +904422316110
}

ÖZ

Çocukların bireysel ve sosyal gelişimlerinde içinde yaşadıkları fiziksel çevrenin etkisi giderek daha çok kabul edilmektedir. Bu makale, Çocuk Dostu Kent yaklaşımı çerçevesinde çocuk ve kentsel mekân ilişkisini, çocuk oyun alanları üzerinden tartışmaktadır. Bu amaçla Erzurum kentinde farklı kentleşme dinamikleri ile öne çıkan üç mahalledeki çocuk oyun alanlarının erişilebilirlikleri ve alansal büyüklük açısından yeterlilikleri incelenmiştir. Erişilebilirlik analizleri için farklı yaş gruplarının değişen ihtiyaçları dikkate alınmıştır. Ayrıca çocukların hem bu alanları hem de sokak ve diğer kentsel boşlukları nasıl kullandıkları da gözlemlenmiştir. Bu analiz ilk olarak tarihsel süreçte kentsel mekân oluşumunda gözlemlenen farklılıkların çocuk oyun alanları açısından da farklı uygulamaları öne çıkardığını göstermiştir. İkinci olarak, bu analize göre tüm bölgelerde 11 yaş altı çocukların oyun alanlarına erişimi sorunlu, çocuk oyun alanı varığı alansal büyüklük bakımından yetersizdir. Üçüncü olarak, kentsel mekânların çocuklar tarafından kullanımı sosyo-ekonomik yapıdan etkilenmektedir. Öncelikle yasal mevzuatımızda çocuk oyun alanlarının büyüklüğü ve kentsel alan içindeki dağılımına ilişkin bir standart belirlenmeli ve çocuk oyun alanları konusunda bazı zorunluluklar tanımlanmalıdır. Diğer kentsel mekânlar çocukların kullanımı açısından güvenliği artacak şekilde yeniden tasarlanmalıdır. Her ilde yoğun bir şekilde devam eden kentsel dönüşüm projeleri, kentlerdeki bu gibi sorunları çözmek ve herkes için daha yaşanılabilir kentsel mekânlar oluşturmak için bir fırsata dönüştürülebilir.

Anahtar Kelimeler: Çocuk Dostu Kent, Oyun Alanları, Erişilebilirlik, Alansal Yeterlilik, Erzurum

\section{Relationship between Child and Urban Space: Accessibility and Areal Efficiency Analysis of Playgrounds in Erzurum}

\begin{abstract}
The effect of physical environment on cognitive and social development of children is highly admitted. Thus, this article discusses the relation between child and urban space through playgrounds within the perspective of Child Friendly Cities Approach. For this purpose, accessibilities and areal efficiencies of playgrounds within three different regions of Erzurum, selected due to their different urbanization processes, are examined. Changing needs of different age groups are considered for the accessibility analysis. Practices of children to use playgrounds, streets and other urban spaces are also observed. This analysis, firstly, puts forward that applications related to playgrounds varies due to the varieties of urban space formation through time. Secondly, the playgrounds are not accessible for children aged under 11 and have areal efficiency problems within all regions. Thirdly, the usage of urban space by children is affected by their socio-economic situations. Thus, it is a priority to determine a legal obligation about the size and distribution of playgrounds within urban space through regulations. Moreover, other urban spaces must be redesigned
\end{abstract}


to be more secure for their everyday usage by children. The ongoing urban transformation projects at all cities should be used as an opportunity to solve these issues and provide more livable urban spaces for all.

Keywords: Child friendly cities, playgrounds, accessibility, areal efficiency, Erzurum

\section{Giriş}

UNICEF'in yürüttüğü Çocuk Dostu Kentler Girişimi'nin internet sayfasında aşağıdaki ifadeler yer almaktadır (URL-1, 2019):

"Her çocuk, kendini emniyette ve güvenli hissettiği, temel hizmetlere ve temiz hava ve suya erişebildiği, oynayabildiği, öğrenebildiği ve büyüyebildiği, ayrıca seslerinin duyulduğu ve önemsendiği bir çevrede büyüme hakkına sahiptir."

Birleşmiş Milletler Çocuk Hakları Sözleşmesi (31.Madde), çocukların yaşadıkları şehirlerde sağlıklı ve güvenli ortamlara sahip olma haklarından ve gelişimleri için uygun fiziksel, sosyal ve kültürel ortamlara sahip olmaları gerektiğinden bahsetmektedir. Görüldüğü gibi çocuklar için yaşanabilir çevreler oluşturma hedefi birçok farklı boyutu bir arada içermektedir. Çocuğun içinde yaşadığı fiziksel çevrenin öneminin anlaşılması ve kabul edilmesiyle mekânın çocuklar için daha yaşanılabilir hale getirilmesi amacıyla UNICEF tarafından başlatılan 'Çocuk Dostu Kent' projesi birçok ülkede uygulanmaya başlamıştır. Türkiye'de de 2006-2010 döneminde 12 şehirde de çocuk dostu kent girişimi başlatılmıştır (Tandoğan, 2014).

Ülkemiz şehircilik yazınına görece yeni girmiş bu girişim ilk olarak 1992 tarihli Rio Zirvesi'nde, ardından 1996'da İstanbul'da gerçekleştirilen Habitat II Konferansı'nda sürdürülebilir kentsel gelişmenin sağlanmasının en önemli ayaklarından birinin tüm yurttaşların intiyaçlarının dikkate alınması gerekliliğine yapılan vurgunun bir uzantısıdır. Böylece başlayan 'kentlerin nasıl herkes için daha yaşanabilir mekânlar kılınabileceği' tartışmaları diğer tüm sosyal grupların yanında çocukların da kentsel mekân düzenlemeleri sırasında yeterince düşünülmediğini göstermiştir (Corsi, 2002; Severcan, 2015).

Toplumların çocuklara ilişkin algısı kentsel mekân tasarımlarında çocukların istek ve intiyaçlarına ne kadar önem verildiğini direkt olarak etkilemektedir. Günümüzde halen çocukluk döneminin yetişkinler tarafından kısa süren geçici bir dönem olduğunun düşünülmesi konuya verilen önemi azaltmaktadır (Birol, 2009). Oy verme hakkı olmayan, dolayısı ile siyasi anlamda bir gücü bulunmayan çocukların istek ve beklentilerinin kamusal alanda dile getirme şanslarını da azaltmakta (Churchman, 2003) ve kentsel mekânda çocukların varlığı yetişkinlerin onlar için belirlediği sınırları aşamamak- tadır. Dolayısı ile bu algının zaman içindeki değişimi onların hem toplum içindeki yerini etkilemiş, hem de mekânla kurduğu ilişkiyi değiştirmiştir.

Çocuk ve mekân arasındaki ilişkinin öneminin anlaşılmasıyla birlikte konu çok disiplinli bir bakış açısıyla ele alınmaya başlanmış ve bu durum öncelikle çocukların toplumsal bir aktör olarak ele alınmasını sağlamıştır (James, 2010). Tıpkı toplumun kendisi gibi çocukluk olgusunun da sosyal olarak inşa edildiği kabul edilmiştir. Bu süreçte toplumsal ve bireysel unsurların iç içe olduğu gündelik mekânlar çocuğun kimliğinin inşa edildiği yerler olarak öne çıkmaktadır. Uysal (2015)'ın da vurguladığı gibi çocuğun günlük yaşamının geçtiği ev, okul ve kent öğrenme, gelişme, disiplin, olgunlaşma ve yetenek gibi olgular aracılığıyla çocuğun hem zihnini hem de bedenini düzenleyip kontrol etmektedir. Böylece çocuğun davranışları içinde bulunduğu mekânlar tarafından belirlenirken, çocuğun toplumun bir bireyi olarak gelişimi ve sosyalleşmesi sürecinde sosyal ortam ile fiziksel çevrenin birbirini destekleyici bir şekilde ilişkilendirilmesi gerekmektedir (Tandoğan, 2014; Yalçınkaya, 2015).

Çocuk Dostu Kent (ÇDK) kavramı aslında sadece mekândaki fiziksel düzenlemeleri içermemektedir. En temelde kentsel mekânı da içeren kamu politikalarının belirlenmesi ve uygulanması aşamalarında çocuk haklarını yaşama geçirmeye özellikle dikkat eden, çocukların seslerinin ve intiyaçlarının bu sürecin ayrılmaz bir parçası haline gelmesi için çabalayan bir kentsel yönetim sistemine de referans vermektedir (Ermiyagil ve Gürçınar, 2015). Tüm kent yönetimlerinin verdikleri kararlar ve uyguladıkları politikalar yine kentsel mekânda görünür olmaktadır. Dolayısı ile çocuğun var olduğu/yaşadığı/günlük hayatını sürdürdüğü mekân ile ilişkisinin nasıl kurulduğu; mekânların kullanım süreçleri de düşünülerek çok boyutlu planlama ve tasarım süreçleri sonrasında oluşturulması gerekliliği anlaşılmaktadır. Bir kentin çocuk dostu olabilmesinin öncelikli koşulu o kentte yaşayan çocukların, yetişkinlerle aynı temel hak ve hizmetlerden yararlanabilmeleri, hem yaşadıkları çevrenin hem de oyun oynadıkları kentsel açık alanların güvenliğinden emin olmasıdır (Gökmen, 2008). Böylece güvenli bir şekilde arkadaşları ile buluşup çeşitli paylaşımlarda bulunabilen çocuklar başka çocuklarla birlikte öğrenebilecek ve toplumda bir birey olarak gelişebilecektir. Kent yetişkin bir birey olabilmesi için çocuğun hem fiziksel hem de sosyal gelişimini destekleyen özelliklere sahip olmalı; çocuklara kendilerinin toplumun diğer bireyleri ile eşit bir parçası olduğu mesajını iletebilmelidir (Churchman, 2003). Görüldüğü gibi sadece kentteki oyun alanlarının sayısını 
arttırmak yeterli değildir. Kentsel mekânın kendisinin bu bakış açısıyla düzenlenmesi gereklidir.

Ancak, Türkiye'deki kentleri incelediğimizde ne yazık ki çocuk dostu mekânlar yaratma konusunda oldukça geride olduğumuzu görmekteyiz. Özellikle hızlı ve yoğun kentleşmenin getirdiği sorunlar kentsel mekânın biçimlenmesini oldukça olumsuz etkilemiştir. Kentleşmenin yoğun yaşandığı 1950'li yıllar ile 1980'li yıllarda olduğu gibi, inşaat odaklı kalkınma ile mekâna müdahalenin hız ve yoğunluğunun arttığı 2000 sonrası dönemde de ne yazık ki bu konu gündem dışı kalmıştır. Oysa Çocuk Hakları ile ilgili gelişmeleri izlediğimizde, Birleşmiş Milletler Çocuk Hakları Sözleşmesi'nden yıllar önce, 1930 yılında Taksim'de okunan Çocuk Hakları Bildirgesi o yıllarda toplumumuzun geleceği çocuklar hakkında ne kadar duyarlı olduğunu göstermektedir. Bu bildiri üç dönem üst üste (5,6 ve 7. Dönemler) Erzurum milletvekili seçilmiş olan Türkiye'nin ilk kadın eğitimcilerinden Nakiye Elgün tarafından okunmuştur (Özdemir, 2014). Makalenin alan çalışması Erzurum'da gerçekleştiği için bu detay daha da önem kazanmaktadır.

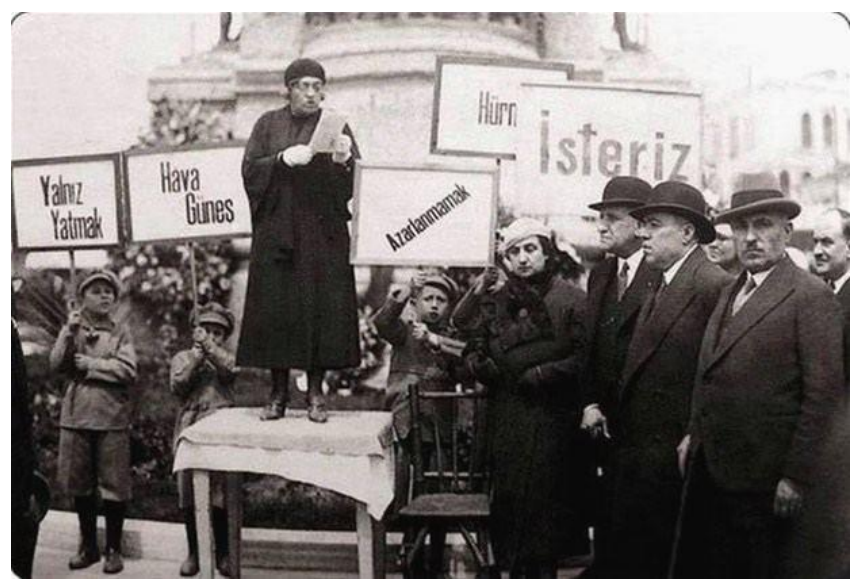

Şekil1: Nakiye Elgün Taksim'de Çocuk Hakları Bildirgesini Okurken, Taksim, 1930 (Özdemir, 2014)

Cumhuriyetin ilk yıllarında var olan bu farkındalığın izlerini daha sonra 1933 tarihli Belediye Yapı ve Yollar Kanunu uyarınca yapılan ilk kent planlarında kentsel mekâna ilişkin verilen planlama kararlarında da izlemekteyiz. Cumhuriyet dönemi ilk imar yasası olarak kabul edilen bu kanuna göre kentsel alan kullanımlarının dağıIımı hesaplanırken kişi başına $4 \mathrm{~m}^{2}$ 'nin yeşil alan olarak ayrılmasının yanında planlarda oyun yerleri için özel alanlar ayrılması da zorunlu kılınmıştır. Bu dönem yapılan ilk planlarda kentsel alanda $300 \mathrm{~m}$ erişim mesafesinde çocuk oyun alanları yer almıştır (Ersoy, 2017).

Ancak zamanla bu duyarlılığın yok olduğunu, kentlerimizde çocuk dostu mekânlar yaratma konusunun yeterince önemsenmediğini mevcut imar yönetmeliğimizden de izleyebilmekteyiz. 3194 sayılı İmar Kanunu ve ilgili yönetmelik uzun yıllar boyunca kentlerdeki minimum aktif açık yeşil alanın kişi başına $7 \mathrm{~m}^{2}$ olarak hesaplanması gerektiğini vurgularken, çocuk oyun alanlarına ilişkin bir zorunluluk ya da başka bir detay tanımlamamıştır. 2014'ten bu yana geçerli olan 'Mekânsal Planlar Yapım Yönetmeliği'nde (URL-2, 2014) ise görece daha hassas bir yaklaşımla erişilebilirlik esasları tanımlanmış, açık yeşil alan olarak tanımlanmış alanlar içerisinde yer seçebilecek kullanımlar arasında çocuk oyun alanları da belirtilmiştir. Tüm bu alan kullanımları için 'Sosyal Açık Ve Yeşil Alanlar' olarak minimum $10 \mathrm{~m}^{2}$ yer ayrılması gerektiği belirtilmiştir. Görüldüğü gibi ilk mevzuatımızdaki zorunluluk tanımı kentlerimizin imar durumunu belirleyecek son yönetmeliğimizde de bulunmamaktadır. Ancak 'Mekânsal Planlar Yapım Yönetmeliği'nde çocuk bahçeleri için 500m hizmet etki alanı tanımlanması, her ne kadar farklı yaş gruplarının intiyaçları göz ardı edilse de, oldukça olumlu bir gelişme olarak kabul edilmelidir.

Bu makale, çocuk ve mekân ilişkisinin doğru şekilde kurulmasının Çocuk Haklarının gerçekleştirilebilmesi için öneminin farkında olarak, kentlerimizde çocuk ve mekân arasındaki mevcut ilişki biçimini araştırmaktadır. Her ne kadar Çocuk Dostu Kent yaklaşımının vurguladığı bu ilişkinin niteliği çocuk oyun alanlarının sayı ve nitelikleri ile sınırlanamasa da, ülkemizde henüz çocuk oyun alanlarının tasarımda ve yer seçimlerinde dahi bu konuda bir duyarlııık oluşmadığını görmekteyiz. Üstelik kentlerimizde çocuklar için tasarlanan çocuk oyun alanları bile ne yazık ki çocuklar tarafından yeterli yoğunlukta kullanılamamaktadır. Dahası her kentte neredeyse birbirinin birer kopyası haline gelen bu alanlar, çocukların yaratıcılıklarını, gelişimlerini ve onların toplumun bir bireyi olarak varoluşlarını desteklemekten de oldukça uzak mekânlardır. Bu durumun en temel sebeplerinden biri söz edilen oyun alanlarının tasarımıyken, diğer etmen ne yazık ki kentlerimizin araç trafiği esas alınarak tasarlanmasıdır. Bu nedenle sayı ve büyüklük bakımından yeterli oldukları kentsel bölgelerde dahi erişimin zorluğu nedeniyle birçok oyun alanı yeterince kullanılamamaktadır.

Bu çalışma ile ülkemizde kentleşme dinamiklerinin çocukların mekânla ilişkisini nasıl etkilediği ve belirlediği sorunsalına bir giriş yapılmak istenmektedir. Bu noktada, en azından başlangıç olarak, Erzurum kentsel alanındaki yeşil alanların ve özellikle çocuklar için tasarlanan mekânların (çocuk oyun alanlarının) kent bütününde erişilebilirlikleri ve yeterlilikleri incelenmiştir. Bu çalışmada çocukların farklı yaş gruplarına göre değişen eğilimleri ve intiyaçları da dikkate alınmış ve özellikle erişilebilirlik analizleri bu çerçevede yapılmıştır. 


\section{MATERYAL VE YÖNTEM}

Bu çalışma kapsamında Erzurum kentinde kentsel gelişme ve yerleşim niteliklerinin farklılıkları bağlamında üç mahalle belirlenmiş (Dadaşkent, Yunusemre ve Yenişehir mahalleleri) ve bu mahalleler arasında karşılaştırmalı bir analiz yapılmıştır. Öncelikle her bir bölgenin temel niteliklerini ve farklılıklarını ortaya koymak adına kentsel gelişim tarihleri araştııılmıştır. 2018 Temmuz ve Ağustos aylarında bu mahallerde yapılan arazi kullanım çalışmaları ile mevcut yeşil alan ve parklar ile çocuk oyun alanları haritaya işlenmiştir. Ayrıca günün farklı saatlerinde çocukların oyun pratikleri gözlemlenerek hem kendileri için tasarlanan bu alanları hem de bu alanların dışında sokak ve diğer kentsel boşlukları nasıl kullandıkları da incelenmiştir. Ardından her bir mahalle sahip olduğu çocuk oyun alanlarının yeterliliği (sayı ve büyüklük) ve erişilebilirliği Piaget'in dönemsellik kuramı çerçevesinde değerlendirilmiştir.

Bu bölümde öncelikle çocuğun mekânsal intiyaçlarını belirleyen gelişimsel dönemleri tartışılarak analizde kullanılacak erişilebilirlik ve yeterlilik ölçütleri tanımlanmış, ardından çalışma alanına ilişkin temel bilgiler verilmiştir.

\section{Çocuğun Gelişimini Belirleyen Temel Dönemler}

Günümüzde ulusal ve uluslararası mevzuat tarafından çocuk henüz 18 yaşını doldurmamış bireyler olarak tanımlanmaktadır. Ancak tüm bu mevzuatlarda belki de yaş tanımlamasından daha önemli olan vurgu çocukların "korunmaya muhtaç" bireyler olmasına yapılan vurgudur (Koç ve ark., 2015). Dolayısı ile çocukları tanımlarken onların biyolojik ve fiziksel yetersizliklerine, olgunlaşıyor olmalarına ve bu geçici süreçte yetişkin yardımına duydukları intiyaç öne çıkmaktadır. Tüm bu ve benzeri nedenlerden dolayı da onların sosyal hayatları ve davranışları yetişkinler tarafından kontrol edilmektedir ve edilmelidir algısı hâkimdir (Erbil, 2016). James ve Prout (1997) bu genel kabulün yanında çocuk tanımında kültürel farklar bulunduğunu da belirtmektedirler. Çocukluk sosyal olarak, içinde bulunduğu toplum tarafından inşa edilmektedir. Ancak çocukluğa ilişkin tanımlar ne kadar değişse de çocukların karar vermedeki becerisine ilişkin nihai sorumluluk her zaman yetişkinlere bırakılmaktadır (James, 2001). Kültürel olarak çocuklara ilişkin algılar ve onlardan beklenenler değiştikçe toplumsal ilişkiler içerisinde onlara biçilen roller de değişmiştir. Bu değişimi hem tarihsel hem de coğrafi olarak izlemek mümkündür (Taşçı, 2010; Köse, 2016).

Modern dönemde toplumsal olarak inşa edilen bir olgu olarak algılanmasıyla birlikte çocukluk dönemine ilişkin bilimsel çalışmalar da hızla artmıştır. Burada odaklanılan en önemli konulardan biri hayatın ilk 18 yılını kapsayan uzunca ve oldukça değişken bir dönem olarak tarif edilen çocukluk döneminin farklı evrelerinin tanımlanması olmuştur. Yapılan birçok farklı çalışma arasında Jean Piaget'in çocukların bilişsel gelişimleri ilgili dönemlemeleri öne çıkmaktadır (Çukur, 2011). Akarsu (1984)'ya göre Piaget, bilişsel mekânizmaları bilen, bilinen ve bunların arasındaki ilişkilerin tanımlanarak işleyişlerinin açıklanması ve ilgili bazı çıkarımlar yapma süreci olarak tanımlar ve kuramında bu mekânizmaların oluşumunu açıklamaya çalışır. Piaget'e göre dönem yaklaşımında belirlenen yaş aralıkları çocuğun fiziksel ve biyolojik yeterlilikleri ile içinde bulunduğu toplum/kültüre bağlı olarak zaman zaman değişse de sıralamanın asla değişmemektedir. Ona göre her dönem kendinden önce gelen dönemlerdeki yapılar üzerine kuruludur. Bilişsel gelişimin yanında mekân kavramını da inceleyen ve bir çocuğun zihinsel gelişim evrelerindeki nitelikleri ve buna göre mekân ile kurduğu değişken ilişkiler üzerinden tanımlayan Piaget, her ikisinin aslında birbiri ile oldukça ilişkili olduğunu da belirtmektedir (Akarsu, 1984).

Piaget'e göre çocuğun mekân algısının gelişimi de bilişsel gelişim dönemleri ile paralel olarak gelişmektedir. İlk iki yıl mekânı duyusal ve devinimsel olarak algılayan çocuk, iki yaşla birlikte onu yeniden canlandırmaya, yani simgesel olarak zihinde de canlandırıp, yeniden üretebilmeye başlar. Ancak bunun için pratikte yaşanmış, eylem ve davranış düzeyinde dengelenmiş bir mekân algısına, mekân deneyimine intiyaç duyar. Gerekli deneyimlerle desteklenebilirse, bu dönemin tamamlanarak somut işlemler dönemine geçilmesi on iki yaşına dek sürer (Akarsu, 1984).

Piaget, çocukta mekân kavramının gelişimini de bu bilişsel gelişim mekânizmaları ile açıklamaktadır (Akarsu, 1984). Topolojik mekân algısı yakınlık, kopukluk, sıradüzen, çevreleme, süreklilik gibi ilk algılarla belirlenen sezgisel bir mekândır. Yaklaşık yedi yaşına doğru çocuk nesnelerin yerlerini ötekilerle ilişkisi çerçevesinde ve belirli bir perspektif içerisinde belirlemeye başlar (Projektif mekân algısı). Nesnelerin yerlerinin ya da aralarındaki ilişkilerin koordinatlarının belirlendiği; yüzey alanları ve uzaklığa ait bilgileri de içeren metrik mekân algısı topolojik mekândan kaynaklanır ve projektif mekâna paralel bir biçimde gelişir.

Çok iyi bilinmektedir ki, çocuk edindiği tüm deneyimleri oyun yoluyla edinmektedir. Piaget'in bilişsel teorisi dönemler kuramı çerçevesinde çocuğun içinde bulunduğu bilişsel aşama ile oynadığı oyunları da ilişkilendirmektedir (Günay, 2016). Buna göre 0-2 yaş grubu pratik/alıştırma oyunları aracılığı ile basit tekrarlar aracılığı ile hem kendi bedeni hem de dış çevre ile ilişki kurmaktadır. 2-7 yaş dönemi ise sembolik oyunlarla önceki dönem edindiği becerileri pekiştirmenin yanında toplumsallığını arttırmaya da başlamaktadır. Böylece nesneler arası ilişkileri mekânsal boyutta çözümleyebildiği gibi toplumsal bir 
varlık olarak ben merkeziyetçiliğin azalması ile kuralların gerekliliği ve önemi de kavranmaya başlar. 7-11 yaş arası ise kurallı oyunlar aracılığı ile içinde bulunduğu grup tarafından önceden belirlenen kurallara göre bir düzenleme yapmayı öğrenmektedir. Görüldüğü gibi oyunun niteliği yaşa bağlı olarak değişmektedir. Bu durum oyun malzemelerinin ve boyutlarının da değişkenlik göstermelerini gerektirir.

Tüm bu tartışmaların bizler açısından önemi, Tablo 1'de de görüldüğü gibi, çocuğun bilişsel mekanizmalarındaki gelişimin mekânsal algısı ile ilişkili bir şekilde gerçekleşiyor olmasıdır. Dolayısı ile çocuğun tüm bu gelişim süreçleri boyunca mekânsal algısının da besleniyor, farklı deneyimlerle destekleniyor olması gerekmektedir. Çocuğun gelişiminde oyunun kendisi hem bilişsel gelişimi hem de mekânsal algısının gelişimini sağlayan bir araç olabilmektedir. Ancak bununla birlikte, bir yetişkin olarak toplum içinde var olacak bireylerin gelişiminde oyunun duygusal gelişime de önemli katkılarının olduğunu göz ardı etmemek gerekir. Zaten daha önce bahsedilen çocukluğun toplumsal inşasındaki farklılık, onun oyun yoluyla diğerleri ile birlikte zaman geçirebilmesiyle ilişkilidir.
Görüldüğü gibi bir çocuğun gelişiminde, kimliğinin oluşumunda ve toplumun bir parçası olarak varoluşunda zihinsel olduğu kadar içinde bulunduğu mekânsal ve toplumsal ilişkileri de oldukça önemlidir. Bu durum, giderek küçülen toplumsal aile yapımızda çocuğun evin dışında, kentsel mekânda diğer çocuklarla oyunlar oynayarak paylaşmayı öğrenmesini geçmişte olduğundan daha da önemli kılmaktadır. Çocukların bu oyunlar yoluyla bedenlerini tanıyarak kendi fiziksel sınırlarını zorlayıp, yeteneklerini test ederken, hayal kurma becerilerinin gelişmesi ve bir şekilde oyunlar aracılığı ile yetişkin yaşamını taklit edebilmesi gerekir. Oyun çocuğun gelişiminde kilit rol oynamakta ve kentin açık mekânlarının çocuğun oyun oynamasını ve yaratıcılığını destekleyen mekânsal karakteristiklere sahip olması gerekmektedir (Birol, 2009). Dolayısı ile kentlerde çocuk oyun alanlarının çocukların burada tanımlandığı gibi gelişimlerini destekleyecek şekilde tasarlanması ve tüm yaş grupları tarafından erişilebilir olması gerekmektedir.

Tablo 1. Piaget'in Zihinsel Gelişim Dönemleri (Akarsu, 1984; Atkinson ve ark., 2006)

\begin{tabular}{|c|c|c|c|c|}
\hline Dönemler & Genel Özellikler & Dönemsel Özellikler & Mekân Algısı & \\
\hline $\begin{array}{l}\text { Duyusal Motor } \\
(0-2 \text { yaş })\end{array}$ & \multirow{2}{*}{$\begin{array}{l}\text { Duyular, algılar ve } \\
\text { sezgiler egemendir }\end{array}$} & $\begin{array}{l}\text { *Kendini nesnelerden ayırt eder } \\
\text { *Kendini eylemi gerçekleştiren özne olarak tanır } \\
\text { ve amaçlı davranışla yapmaya başlar. (bir nes- } \\
\text { neyi harekete geçirmek için ipini çeker ya da gü- } \\
\text { rültü yapmak için çıngırağını sallar } \\
\text { *Nesne kalıcılığı kavramını edinir; nesnelerin } \\
\text { duyumsanmadıklarında da var olduklarını kav- } \\
\text { rar. }\end{array}$ & \multirow{4}{*}{$\begin{array}{l}\text { Duyusal-devi- } \\
\text { nimsel mekân } \\
\text { Yeniden can- } \\
\text { landırılan } \\
\text { mekân }\end{array}$} & \multirow{4}{*}{$\begin{array}{l}\text { Topolojik } \\
\text { mekân } \\
\text { Projektif } \\
\text { Mekân }\end{array}$} \\
\hline $\begin{array}{l}\text { İşlem Öncesi } \\
(2-7 \text { yaş) }\end{array}$ & & $\begin{array}{l}\text { Dili kullanmayı, nesneleri imgeler ve sözcüklerle } \\
\text { belirtmeyi öğrenir. Düşünce hala benmerkezci- } \\
\text { dir. Başkalarının görüş açılarını anlamakta zor- } \\
\text { luk çeker. Nesneleri tek bir özelliğe göre sınıflar. } \\
\text { (tüm kırmızı küpleri biçimlerine bakmadan ya da } \\
\text { tüm kare blokları rengine bakmadan gruplara } \\
\text { ayırır) }\end{array}$ & & \\
\hline $\begin{array}{l}\text { Somut İşlem } \\
\text { (7-11 yaş) }\end{array}$ & \multirow{2}{*}{$\begin{array}{l}\text { Çocuk durumsal } \\
\text { uyarıcılarla etkile- } \\
\text { şime girer } \\
\text { Göreli özerklik ve } \\
\text { bağımsızlık kaza- } \\
\text { narak düşünebilme } \\
\text { yeteneğini gösterir. }\end{array}$} & $\begin{array}{l}\text { Nesne ve olaylar hakkında mantıklı olarak düşü- } \\
\text { nebilir. Sayı (6yaş), kütle (7yaş) ve ağırlık } \\
\text { (9yaş) korunumu kavramlarını edinir. }\end{array}$ & & \\
\hline $\begin{array}{l}\text { Formel İşlem } \\
\text { (11 yaş ve } \\
\text { üstü) }\end{array}$ & & $\begin{array}{l}\text { Soyut önermeler üzerine mantıksal olarak düşü- } \\
\text { nebilir ve varsayımları sistematik olarak test } \\
\text { edebilir. } \\
\text { Varsayımsal, geleceğe yönelik ve ideolojik so- } \\
\text { runlarla ilgilenir. }\end{array}$ & & \\
\hline
\end{tabular}

\section{Çocuk Oyun Alanlarının Erişilebilirlik ve Alansal Yeterlilik Kriterleri}

Yazında çocuk oyun alanlarının hitap ettiği farklı yaş gruplarına göre farklı tanımlara sahip olduğu, buna göre hizmet yarıçaplarının ve minimum alan büyüklüklerinin de değiştiği görülmektedir. Genel olarak 1-3 yaş grubuna hizmet eden alanlar 'çocuk oyun yeri', 3-6 yaş grubuna hizmet eden alanlar 'çocuk bahçesi', 5-16 yaş grubu için tesis edilen alanlar ise 'oyun alanları olarak tanımlanmaktadır. Konut alanları içerisinde, ana ulaşım ağlarından uzakta konumlanması gereken bu alanları 
hedef çocuk grubunun yaşlarına göre yeteneklerini geliştirebilmeleri için olanaklar yaratacak şekilde tasarlanmış olmalıdır. Bu alanların tasarımında sadece farklı oyuncakların bulunması değil, çevredeki doğal örüntü ile de bütünleşerek çocukların yaratıcılıklarının gelişimine fırsat verecek kurguları da içermeleri esastır. Farklı ülke örnekleri incelendiğinde genel olarak bu alanlara ilişkin yasal normların belirlenmediği görülmektedir. Ancak İngiltere gibi ülkelerde sadece çocuk bahçelerinin kişi başına $10 \mathrm{~m}^{2}$ ye ulaşabildiği görülmektedir. Ülkemizde ise Ankara Nazım Plan Bürosu'nun önerdiği normlar çocuk oyun yerleri için kişi başına $2 \mathrm{~m}^{2}$, çocuk bahçeleri için ise $1 \mathrm{~m}^{2}$ olmuştur. Ancak Türkiye'deki yeşil alanların yeterliliğini inceleyen çalışmalar ne aktif yeşil alan varlığının ne de çocuk oyun alanlarının mevzuatla belirlenen minimum sınırlara dahi yaklaşamadıklarını göstermektedir (Ersoy, 2015).

Kentlerde çocuk oyun alanlarına ilişkin henüz kesin bir norm belirlenememiş olsa da bu konudaki çalışmalar devam etmektedir. Bazı çalışmalar kentlerde ayrılması gereken çocuk oyun alanlarının belirlenmesinde kişi başına ayrılması gereken minimum metrekareye odaklanırken (öneriler 4 ila $6,5 \mathrm{~m}^{2}$ arasında değişmektedir), kimi çalışmalarda ise bölgedeki çocuk nüfusu üzerinden (genel olarak $6,5 \mathrm{~m}^{2}$ önerilmektedir) bir hesaplamanın yapılması gerektiği üzerinde durmaktadırlar. Bununla birlikte araştırmacılar genel olarak en küçük çocuk oyun

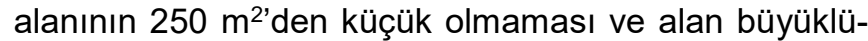
ğünün yerleşim büyüdükçe, özellikle de apartman tipli yapılaşmanın arttığı yoğun kentsel alanlarda $1000 \mathrm{~m}^{2}$ ye dek çıkması gerektiği konusunda uzlaşmaktadırlar (Uzun, 1990; Yılmaz ve Bulut, 2002; Şişman ve Özyavuz, 2010).

Erişilebilirlik analizi Piaget'in dönemsellik kuramı çerçevesinde geliştirilmiştir (Tablo 2). Ancak, çocukluk çağına ait dönemlerde sınır değerler çakışmayı önlemek adına değiştirilmiştir. Böylece hem yeterlilik hem de erişilebilirlik analizlerinin daha kontrollü olması sağlanmıştır. Her bir yerleşim biriminin mevcut durumunun güncellenmesinin ardından çocuk oyun alanlarının mahalle bazında dağılımları ve büyüklükleri irdelenmiştir. Öncelikle Tablo 2'de verilen mesafeler kullanılarak park ve çocuk oyun alanlarının ilgili yaş grupları tarafından erişilebilirlikleri incelenmiş, daha sonra da yine bu alanların büyüklükleri üzerinden en azından hizmet ettikleri bölge açısından yeterlilikleri tartışılmıştır. Bu aşamada çocukluk dönemi olarak 0-14 yaş grubu esas alınmış, çocuk oyun alanlarının yeterlilikleri bu bağlamda değerlendirilmiştir. Ancak, ne yazık ki ülkemizdeki istatistiki veri tabanı her bir mahallede yaşayan çocuk nüfusu konusunda net bir bilgi sunmadığı için ilçe bazında verilen yaş grupları yüzdeleri kullanılarak araştırmanın yürütüldüğü mahallelerdeki 014 yas nüfusu belirlenmiştir. Yapılan yeterlilik analizlerinde bu çocuk nüfusları esas alınmıştır (Tablo 3).

Tablo 2. Çocukların Gelişim Dönemleri Bağlamında Çocuk Oyun Alanlarının Erişilebilirlikleri (Bakan ve Konuk, 1987)

\begin{tabular}{|l|c|c|}
\hline Gelişim dönemleri & Minimum uzaklık $(\mathbf{m})$ & Maximum $(\mathbf{m})$ \\
\hline Duyusal Motor (0-2 yaş) & - & 30 \\
\hline İşlem Öncesi (3-6 yaş) & 30 & 70 \\
\hline Somut İşlem (7-11 yaş) & 100 & 150 \\
\hline Formel İşlem (12 -15/18 yaş) & - & 350 \\
\hline
\end{tabular}

Tablo 3. Çalışma alanı nüfusları (TUiKK 2017 ADNKS verileri)

\begin{tabular}{|l|c|c|}
\hline Yerleşim Biriminin Adı & $\begin{array}{c}2017 \text { ADNKS } \\
\text { Nüfusu }\end{array}$ & $\begin{array}{c}\text { Bölgedeki Yaklaşık Çocuk } \\
\text { Nüfusu (0-14 yaş) }\end{array}$ \\
\hline Dadaşkent & 35653 & $5954(\% 16.7)$ \\
\hline Yunusemre & 46419 & $8216(\% 17.7)$ \\
\hline Yenişehir & 34318 & $6074(\% 17.7)$ \\
\hline
\end{tabular}

Çocuk Dostu Kent olgusunun tartışıması için böyle bir yeterlilik ve erişilebilirlik analizi elbette yeterli olmamaktadır. Yukarıda belirtilen analizlere ek olarak alanda yapılan gözlemlerle sadece analize dâhil olan park ve çocuk oyun alanlarının değil, yerleşim birimlerindeki cadde/sokak ve boş alanların çocuklar tarafından kullanım dinamikleri de incelenmiştir. Böylece çocukların mekân kullanım biçimleri daha yakından incelenmeye çalışılmıştır. Ancak çocukların özgün ve öznel mekân algılarına ilişkin bir çalışma ne yazık ki bu çalışmanın kapsamına dâhil edilememiştir. Bunun en azından mekânsal düzeydeki yeterlilikleri araştıran bir çalışma olarak ilerideki daha detaylı ve kullanıcıları (çocukları) da kapsayan çalışmalar için bir başlangıç olması düşünülmektedir. 


\section{Çalışma Alanı}

Çalışma Erzurum kentinde kentsel gelişim dinamikleri ve diğer özgün nitelikleri ile birbirinden ayrışan üç farklı mahallede gerçekleştirilmiştir (Şekil 2): Dadaşkent, Yenişehir ve Yunusemre Mahalleleri. Erzurum kuzeyde Erzurum Ovası, güneyde Palandöken Dağı ve Batıda Atatürk
Üniversitesi arazisi ile sınırlanan 1850 m yükseklikte bir alana kurulmuştur. Kent yoğun kış koşulları nedeni ile uzun yıllar kompakt bir gelişme göstermiş; ancak 1950'lerden sonra sur dışında yayılmaya başlamıştır. Kent merkezi Erzincan-Erzurum-Kars Karayolu'nun çizdiği yay içinde yer almaktadır. Alan çalışması için seçilen yerleşimler bu yayın güneyinde yer almaktadır.

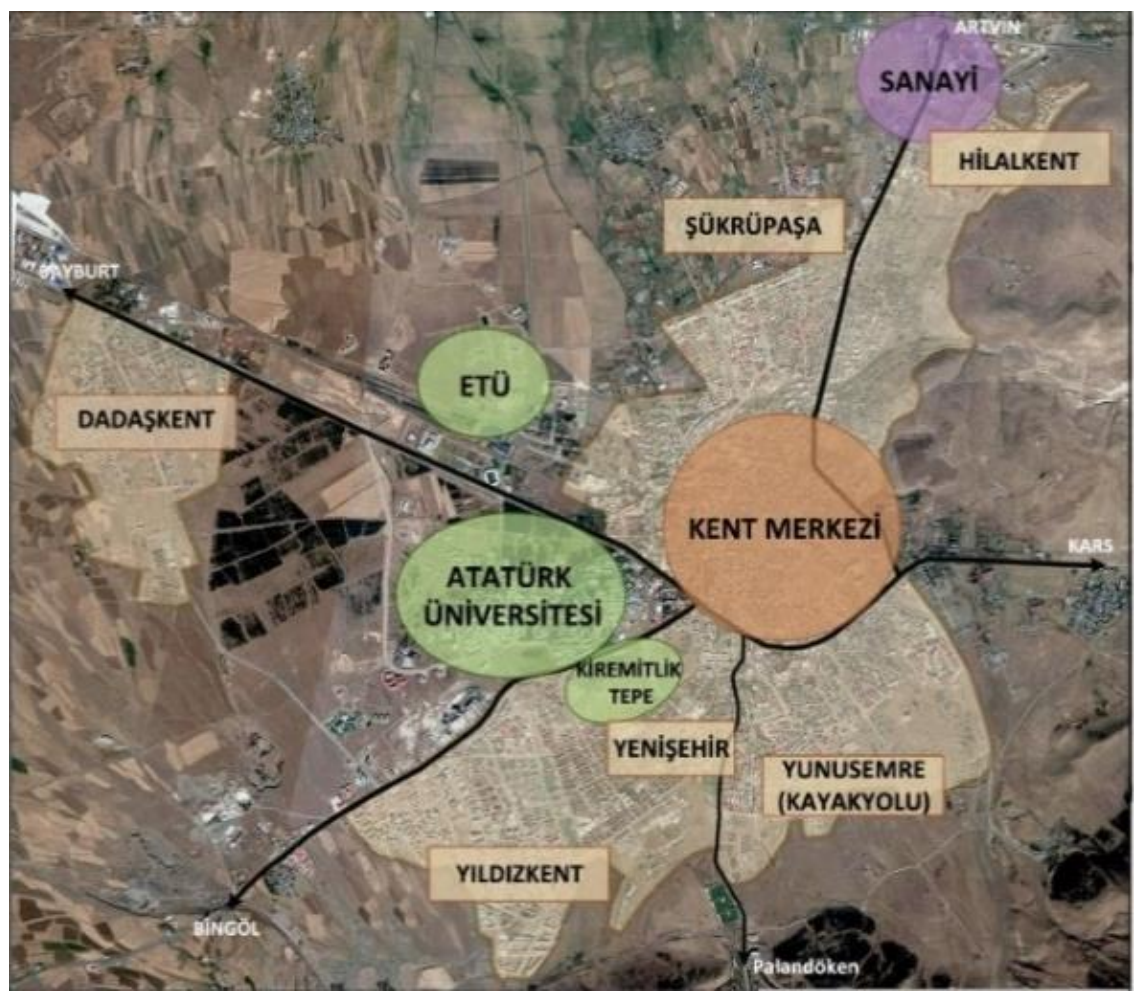

Şekil 2. Çalışma Alanı

Kentin gelişimi 1950'li yıllara dek 1939 tarihli Lambert Planı'nın (kentin ilk imar planı) da tanımladığı merkez alan içerisinde kalmış, ancak bu dönem tüm ülke kentlerinde görülen iç göç dalgasının hızlanmasıyla birlikte kentsel yayılma Erzurum'da da kontrolsüz bir hızla gerçekleşmeye başlamıştır. Lambert'in 100.000 kişi için tasarladığı plan yetersiz kalınca 1967 tarihinde kentin ikinci planı yapılmış (Zeki Yapar Planı) ve bu yayııma alanları kontrol altında tutulmaya çalışımıştır (Dursun, 2015a). Alan çalışmasının yürütüldüğü üç yerleşim bölgesi de 1967 tarihli imar planı ile yerleşmeye açılmış bölgelerdir. Ancak, Erzurum için 1939'dan beri yapılan kent planlarının uygulanması, yapılan itirazlar ve 18.madde uygulamalarında yaşanan sıkıntılar yüzünden sekteye uğramıştır. Bu nedenle kent, her yeni plan arasında uzun süreler plansız bir şekilde gelişmeye devam etmiştir (Dursun, 2015a). 


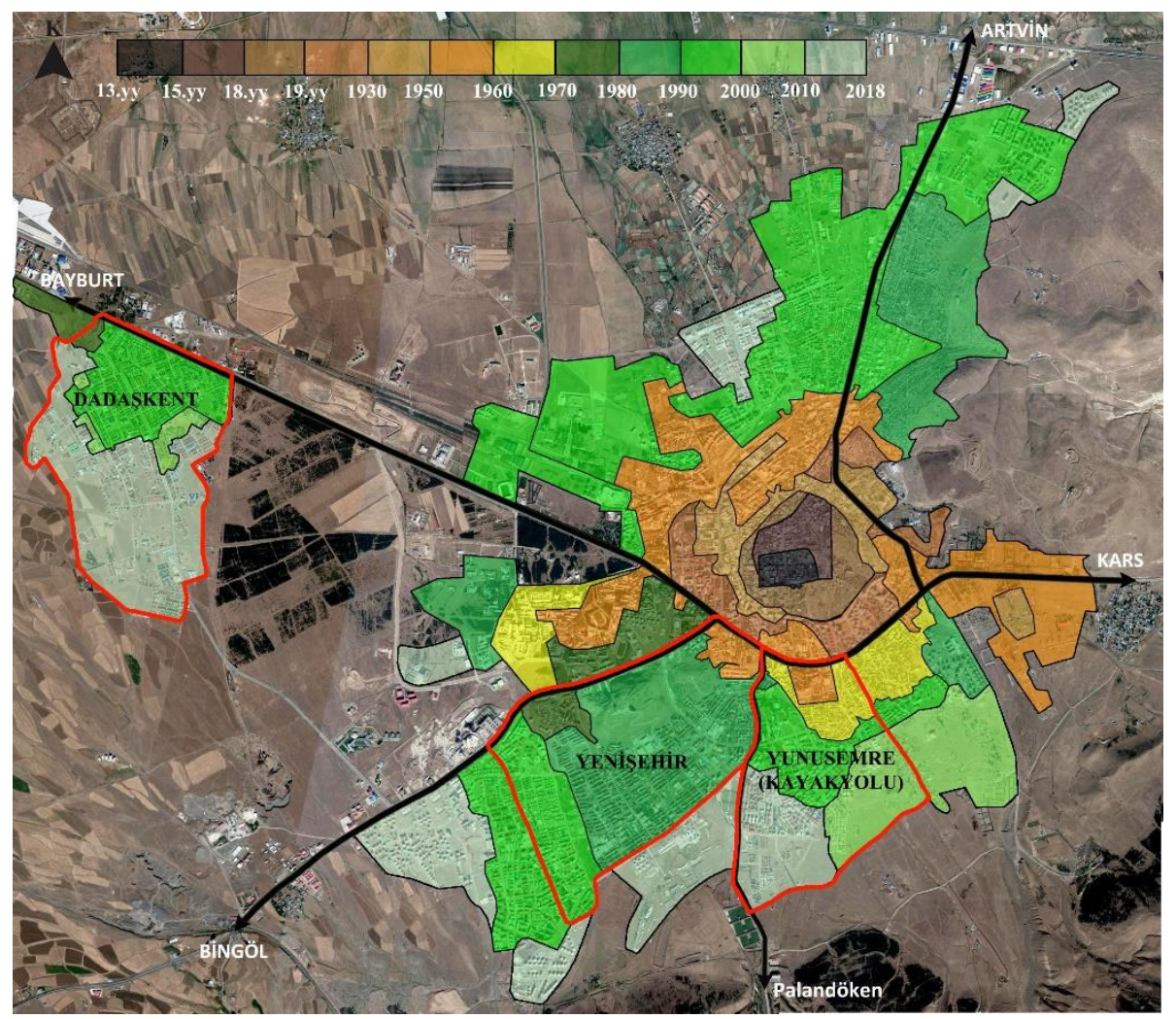

Şekil 3. Erzurum Kenti Tarihsel Gelişimi ve Çalışma Alanları

(Erzurum Büyükşehir Belediyesi Koruma Amaçlı İmar Planı Raporundan alınan veriler ile uydu fotoğrafları kullanılarak yazarlar tarafından üretilmiştir)

Zeki Yapar Planı'nın mevcut kentsel büyümeyi etkileyen en önemli plan kararlarından biri kentsel büyüme için uydu kentler önermiş olmasıdır. Dadaşkent de bu uydu kentlerden biri olarak gelişmiştir. 1985 plan nüfusu olarak önerilen 489.590 kişinin 132.456'sının Erzurum kent merkezinde yerleşmesi, kalan nüfusun kentin batı aksında Erzincan yolu üzerinde sırasıyla beş ve on iki km uzaklıktaki Gezköy ve llıca yerleşmelerinde ikamet etmesi öngörülmüştür (Dursun ve ark., 2015); Dursun ve Yavaş, 2015). Bu öneri özellikle Gezköy çevresindeki arsa spekülasyonlarını artırmıştır. Arsa fiyatları Erzurum geneline göre oldukça yüksek olan bu bölgede (özellikle Gezköy'de) yerleşme 1970'lerle birlikte kaçak yapılaşmanın da etkisiyle hızla artmıştır. 1990 yılından itibaren Gezköy ile Üniversite alanı arasında yeni bir uydu kent olarak Dadaşkent ortaya çıkmaya başlamıştır. Zemin yapısı nedeniyle önceleri sadece 1-2 kata izin verilen ovada daha sonra kat yükseklikleri yer yer 5 kata kadar çıkarılmıştır. Gezköy daha çok gelir düzeyi düşük gruplar ikamet ederken, yapılaşma şartlarının da getirdiği sınırlamalar nedeniyle yeni kurulan Dadaşkent öncelikle 1-2 katlı villalarda ikamet eden kentin görece seçkinlerinin yerleştiği bir bölge haline gelmiştir. Zamanla hem kat yüksekliklerinin kısmen artması hem de 2-3 katlı yapılarda da apartman tipi yapılaşmaya gidilmesi ile orta-üst gelir grubu da bölgeye yerleşmeye başlamıştır.
Gezköy Bölgesi bugün kentsel dönüşüme konu olduğu için tamamen yıkılırken, planlı bir şekilde gelişmeye başlamış olan Dadaşkent Bölgesi, 2015 tarihli planın da etkisi ile güneye doğru gelişmesine hızla devam etmektedir.

Çalışmanın yürütüldüğü ikinci bölge olan Yunusemre Mahallesi ise kentsel gelişim dinamiklerindeki (Şekil 3) farklılıklara paralel olarak üç farklı mekânsal yapıya sahiptir. 1960'lı yıllarda kente göç edenlerin önemli bir kısmı kent merkezinin çeperine, Erzincan-Kars yolunun çizdiği yayın hemen güneyine yerleşmişlerdir. Önemli bir kısmı kamu bölgesi olarak işlev gören (1950-1960 arası yapılaşmış) bu ilk yerleşim bölgesi genel olarak 1-2 katlı yapısını korumakta, ancak bölge halkının artan gelir seviyesine paralel olarak yıkıp yeniden yapma yoluyla 3-4 katlı yapılaşmaya doğru zaman içinde hızla değiştiği görülmektedir. Bölgedeki mevcut ulaşım sistemi ise aynı plansızlığı korumaktadır. Bu bölgenin hemen güneyinde, bugün Kayakyolu diye anılan bölge ise Zeki Yapar Planı sonrasında yaklaşık 20.000 nüfus öngörüsü ile gelişmeye açılan bir bölgedir (Dursun ve ark., 2015). Planda Palandöken Dağları'nın eteklerindeki bu bölge için var olan dokunun tersine modern ve çok katlı blokların oluşturulması önerilmiştir. Planlama döneminde bu öneri gerçekleşememiş olsa da 1990 ve sonrasında bu bölge 
6 kat ve üzerindeki çok katlı yapılarla hızla gelişmiştir. Yoğunluğu oldukça yüksek olan bu bölgede dolu-boş alan dengesinin de yeterince kurulamadığı, planlı dönem sonrasında gelişmiş bir bölge olmasına rağmen uygulamada yol güzergâhlarının oldukça karmaşık olduğu ve trafiğin (taşıt ve yaya) yeterince yönlendirilemediği görülmektedir. Aynı mahalle sınırları içerisinde, 2000 sonrasında Palandöken sırtlarına doğru yeni bir gelişme dinamiği başlamıştır. Burada 2 katlı, geniş bahçelere sahip villaların bulunduğu, kentin zenginlerine hitap eden yeni bir konut bölgesi oluşmuştur. Günümüzde bu bölgedeki yapılaşmanın hızla devam ettiği gözlenmektedir.

Çalışma kapsamında ele alınan üçüncü bölge ise Yenişehir mahallesidir. Bu bölge genel itibariyle 1980-1990 yılları arasında kentteki gecekondu sorununa bir çözüm üretebilmek amacıyla kooperatifler eliyle inşa edilmiş bir bölgedir. Oldukça yoğun olan bu kentsel bölgede planlı gelişim sayesinde yeşil alanlara oldukça fazla yer verilmiştir (Dursun ve Yavaş, 2015). Yerleşim bölgesinin ilk gelişim alanı olan Köşk bölgesi 1950-1960 yılları arasında kentin ilk planına da uygun bir şekilde kamusal yapıların yoğun olarak bulunduğu bir alandır. 1970-1980 yılları arasında kentteki yoğun gecekondulaşmanın bir etkisini bu bölgede de izleyebilmekteyiz. Erzurum'da gerçekleşen Universiade 2011 Kış Oyunları kapsamında bir kısmı yıkılmış olan gecekondu bölgesinden kalan izler halen görülebilmektedir. 1980-1990 yılları arasında yapılaşan bölgede planlama/tasarım ve uygulama aşamalarında açık ve kapalı alan dengesinin kurulmasına özellikle dikkat edildiği, sokak ve caddelerin yönlendirilmesinde hâkim rüzgâr yönünün esas alındığı, yapılar arasındaki boşluklar belirlenirken kış koşullarının dikkate alındığı görülmektedir. Orta yoğunluktaki bu bölgede daha çok beş katlı yapılar bulunmakta, görece daha geniş caddelere sahip bölgede ulaşım ve açık yeşil alan düzenlemelerinin de kentin diğer bölgelerine göre daha planlı gerçekleştirildiği ve yaşanılabilir bir bölge oluşturduğu görülmektedir (Dursun, 2015b). Mahallenin 19902000 yılları arasında yapılaşan bölgesi bu bölgeden kuzey-güney doğrultusunda uzayan eski dere yatağı üzerine konumlandırılmış bir parkla ayrılmaktadır. Ancak bu bölgedeki yapılaşma ilkeleri incelendiğinde, bir önceki dönem uygulanan ilkelerin esas alındığı görülmektedir. Bununla birlikte daha üst gelir grubuna hitap eden iki katlı yapıların (villa) bulunduğu bir alt bölgeye de sahip- tir. Bu yeni yerleşme bölgesinin kuzeyinde, eski dere yatağının bulunduğu bölgede yapılaşma halen devam etmektedir. İlerideki analizlerde de görülebileceği gibi 11 yaş altı çocuklar için gerekli çocuk oyun alanları konusunda en sorunlu bölge de burasıdır.

\section{BULGULAR VE TARTIŞMA}

Bu bölümde öncelikle üç mahalledeki yeşil alanlar ve çocuk oyun alanlarının erişilebilirlikleri, Piaget'in gelişimsel dönemleri bağlamında incelenmiş, ardından bu alanların mahallelerdeki çocuk nüfusları ve çocuk oyun alanlarının büyüklükleri çerçevesinde yeterlilikleri incelenmiştir.

\section{Çocuk Oyun Alanlarının Erişilebilirlik Analizi}

Dadaşkent yerleşmesi kuzey batı-güneydoğu aksında bulunan ana cadde ile iki mahalleden oluşmaktadır. Bu ana caddenin doğusunda kalan Selçuklu Mahallesi (16071 kişi) Dadaşkent'in ilk kurulduğu bölge olup, daha çok 1-2- katlı, bahçeli konutların egemen olduğu bir yapıya sahiptir. Yolun batısındaki gelişimi özellikle 1990'lardan itibaren hız kazanmış Saltuklu Mahallesi (19582 kişi) ise 3 kat ve üzeri bir yapılaşmaya sahiptir. Zamanla anayolun her iki yanında da kat yüksekliğinin artması ile bu cadde Dadaşkent'in merkezi haline gelmiş, bölen değil, birleştirici bir unsura dönüşmüştür. Ancak Şekil 3'de de görüldüğü gibi yapı ve nüfus yoğunluğu daha fazla olan bölgelerde ne yazık ki açık ve yeşil alanlara çok daha az yer verilmiştir. Yerleşimin ilk kurulduğu, ağırlıklı olarak bahçeli evlerin bulunduğu kuzey bölgelerde nüfus yoğunluğu çok daha az olmasına rağmen, açık-yeşil alan ve çocuk oyun alanlarının görece daha yoğun olduğu gözlenmektedir. Oysa apartman tipi yapılaşmanın arttığı orta bölgede açık yeşil alan sayısının giderek azaldığı, 2010 sonrasında yapılaşmanın hızla artan daha güney kesimde ise açık yeşil alan yapımına hiç yer verilmediği görülmektedir. Burada ülke genelindeki inşaat odaklı kalkınma stratejisinin de etkisiyle gerçekleşen hızlı yapılaşmanın sonuçları görülmektedir. Ne yazık ki belediyeler sorumlulukları altında olan gerekli sosyal altyapı alanlarının sunumu konusunda inşaat sektörünün hızına yetişememektedir. Bunun sonucunda da büyük alanlar kentleşmesine rağmen, açık-yeşil alan gibi ortak kullanım alanlarının sunumu oldukça geç kalmaktadır. 


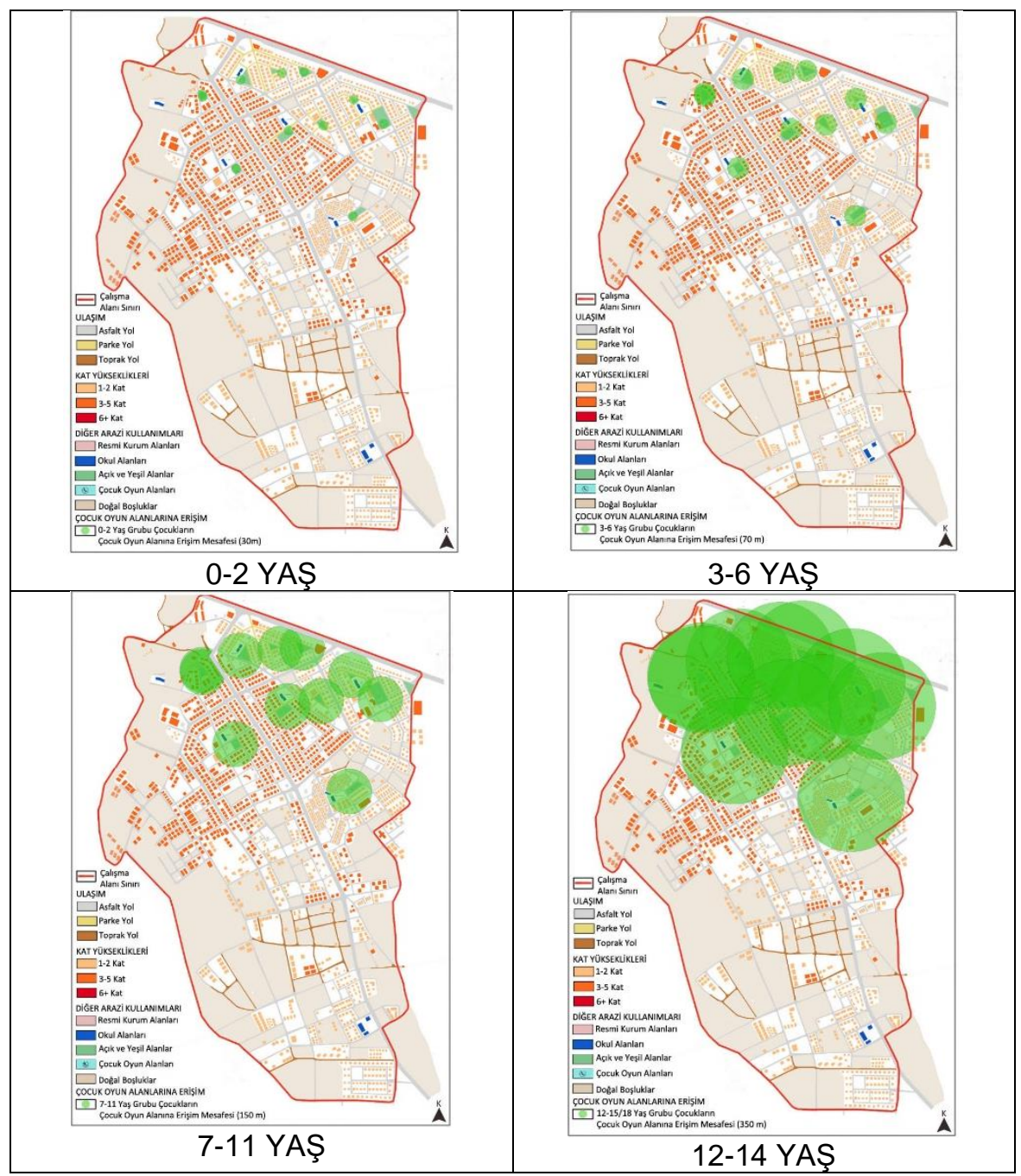

Şekil 4. Dadaşkent Bölgesinde Yeşil Alanlar ile Çocuk Oyun Alanlarının Dağılımı ve Erişilebilirlik Açısından Analizi

Şekil 4 Dadaşkent'teki parkların çocuklar açısından erişilebilirliğini göstermektedir. Şekilden de izlenebileceği gibi çocukların veli gözetimine daha bağımlı olduğu 0-6 yaş aralığı için ciddi bir erişim sorunu bulunmaktadır. Her ne kadar çocuk bu dönemde ebeveyni ile birlikte, çoğu zaman da çocuk arabası ile kentte gezse de, bu uzaklıklar ebeveynler açısından da çocuğu dışarı çıkarma konusunda bir caydırıcı olmaktadır. Özellikle de Erzurum gibi bir kış kentinde mesafelerin konuta uzaklığı ve bir yaya yolu sistemi üzerinden birbirleri ile ilişkilenmiyor oluşu bu parkların etkin kullanımını da zorlaştırmaktadır. Görece ebeveynlerden bağımsızlığın başladığı 7-11 yaş açısından da durum pek iç açıcı değildir. İlkokul çağı olarak da adlandırabileceğimiz bu dönem için erişilebilirlik haritasını incelediğimizde parkların genellikle okulların hemen yanında olduğunu görebiliriz. Bu durum okula yaya ulaşımın gerçekleşmesi durumunda parkların da çocuklar tarafından etkin kullanılabileceğini gösterse de, araç bağımlı bir ulaşım sistemine sahip olan Dadaşkent için bunun pek de olası olmadığı görülmektedir. 12 yaş ve üstü için yapılan inceleme erişilebilirlik açısından daha olumlu bir sonuç vermektedir. Ancak yerleşimin güney bölgesinde hiç park olmaması, artık bağımsızlaşmış, kentsel mekânda daha çok vakit geçirebilecek, böylece toplumda bir yetişkin olarak var olmanın en somut pratiklerini gerçekleştirecek bu yaş grubu çocukları için kentin kendisini de erişilemez kılmaktadır.

Dadaşkent bölgesinde yapılan gözlemlerin ortaya koyduğu bir başka husus da ne parkların ne de cadde ve sokakların neredeyse hiçbir yaş grubu çocuk tarafından etkin olarak kullanılmamasıdır. Erzurum genelinde açık yeşil alan tasarımında çocuk oyun alanları ile kamelyaların bulunduğu açık alanlar bir arada düşünülmektedir. Böylece en azından bahar ve yaz aylarında aileler bu yeşil alanlarda vakit geçirirken, çocuklar da oyun alanlarında birlikte olabilirler. Ancak yapılan gözlemlerde okulların tatilde olduğu yaz dönemi olmasına rağmen çocuk oyun alanlarında sadece birkaç çocuğun bulunduğu, ço- 
ğunun da boş olduğu gözlenmiştir. Aynı bölgelerde günün farklı saatlerinde yapılan gözlemler bu durumu desteklemektedir. Aynı şekilde ara sokak ve caddelerde de durum değişmemektedir.

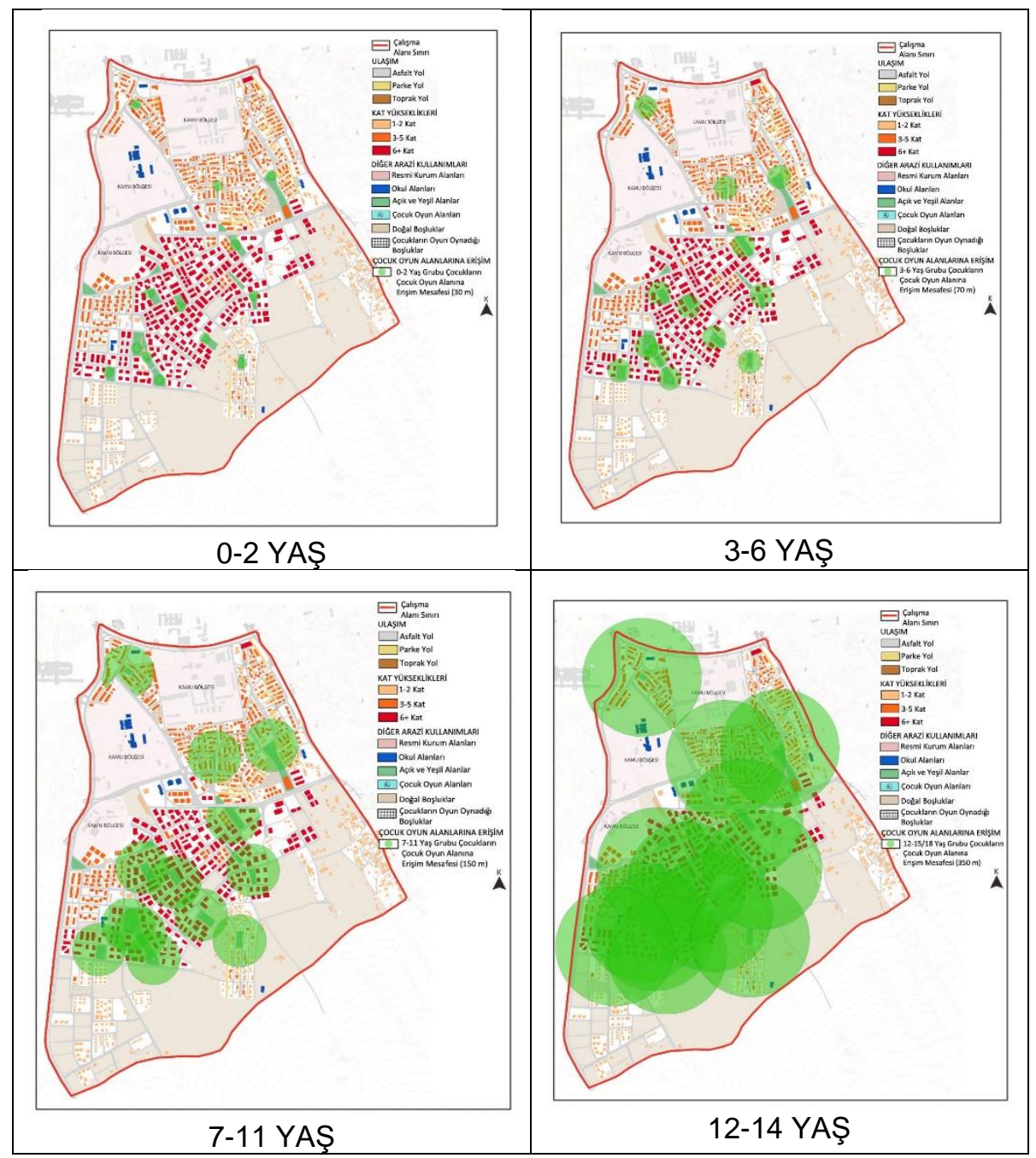

Şekil 5. Yunusemre Mahallesi'nde Yeşil Alanlar ile Çocuk Oyun Alanlarının Dağılımı ve Erişilebilirlik Açısından Analizi

Şekil 5'de Yunusemre mahallesindeki parkların konumları ve farklı yaş grupları tarafından erişilebilirlikleri verilmiştir. Yukarıda bahsedilen üçlü yapı burada da kendini göstermektedir. Mahallede kentleşmenin ilk kez gerçekleştiği kuzey bölgesinde içinde çocuk oyun alanının da olduğu sadece 3 adet park bulunurken, çok katlı yapılaşmanın gerçekleştiği Kayakyolu bölgesinde planlı gelişmenin de etkileri ile oldukça çok sayıda park yapıldığı görülmektedir. Daha güneydeki yeni gelişen villalar bölgesinde ise Dadaşkent'in güneyindeki gibi hiç açık yeşil alan ve çocuk oyun alanı yapılmadığı gözlenmektedir.

Çocuk oyun alanlarının erişilebilirlik açısından analizi 06 yaş grubu için benzer sonuçlar vermektedir. Ancak eğim açısından daha dik yolların bulunduğu bölge için bu parklara bebek arabalarıyla ya da çok küçük çocuklarla erişim daha da zorlaşmaktadır. Kayakyolu bölgesinde daha çok site tipi yapılaşmanın olması asıında bir avantaja dönüştürülebilecekken yapılan analizler ne yazık ki öyle olmadığını göstermektedir. Sitelerdeki boşluklar oralarda ikamet edenlerin açık yeşil alan intiyacının karşılanması amacıyla değil, birer otopark alanı olarak kullanılmaktadır. Bu durum özellikle 0-6 yaş arası çocukların da erişimi güç olan mahalle parklarına gitmelerini gerektirmektedir. Ancak arazide yapılan gözlemler bölgedeki parkların bu yaş grubu tarafından etkin bir şekilde kullanılmadığını göstermektedir. 7-11 yaş grubu 
açısından mahalle parklarının erişilebilirliği incelendiğinde görece daha dengeli bir dağılım olduğu görülmektedir. Yunusemre mahallesinin kuzey bölgesinde bazı alanlar parklara erişimde sorun yaşasa da bölgenin önemli bir kısmının kamu bölgesi olarak kullanılması park alanlarına erişemeyen konut bölgelerinin daha küçük bir bölge olmasını sağlamıştır. Kayakyolu bölgesinde ise parkların sayısının görece fazlalığına rağmen, yer seçimleri nedeniyle özellikle 3 alt bölgede 7-11 yaş grubu çocukların erişebileceği herhangi bir park alanı olmadığı ortaya çıkmaktadır. En güneyde villaların olduğu bölgede ise zaten hiçbir açık yeşil alan olmadığı için, bu bölgede çocuklarının mekânla ilişki kurabildikleri tek alan kendi evlerinin bahçeleridir. Ancak bu durum çocukların diğer çocuklarla raslantısal olarak bir araya gelebilecekleri fırsatları da yok etmektedir. Erişilebilirlik mesafesinin 350m'ye ulaştığı 12-14 yaş grubu için ise Yunusemre Mahallesindeki durum çok daha olumludur. Bölgenin neredeyse hepsi bu yaş grubu için açık yeşil alanlar açısından erişilebilirdir. Sadece hiç park bulunmayan üçüncü alt bölge sorunlu görülmektedir.

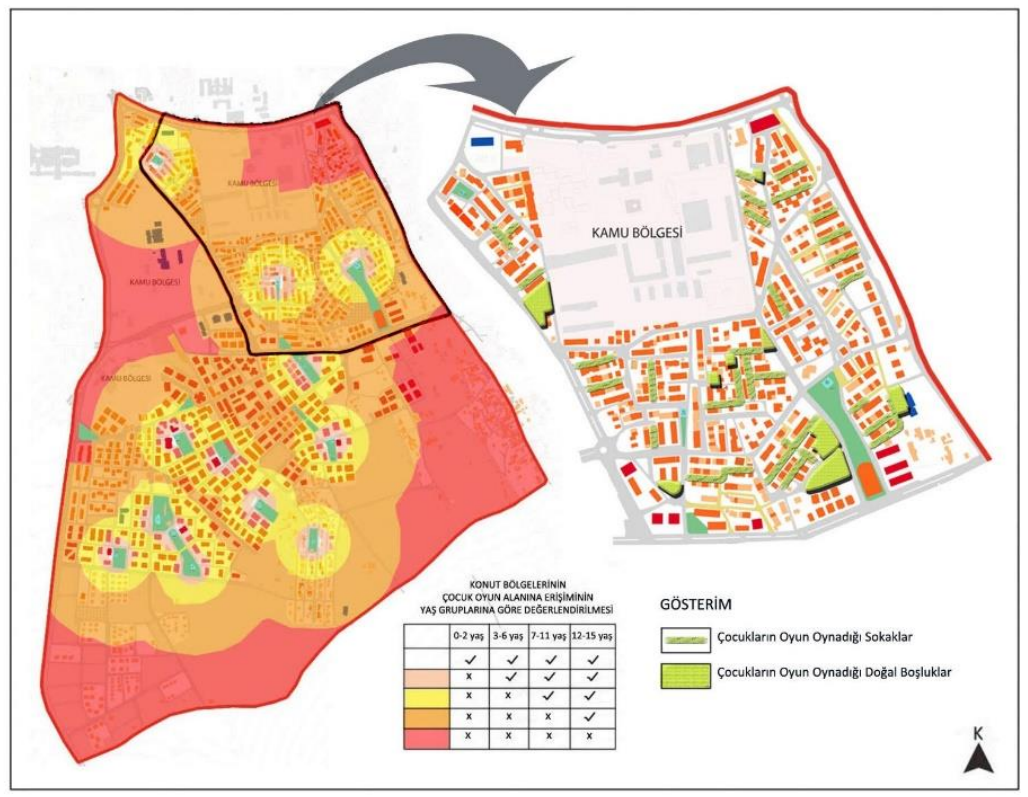

Şekil 6. Yunusemre Mahallesi ilk yerleşim bölgesinde çocukların oynadıkları alanlar

Bununla birlikte boş alanlarla cadde ve sokakların çocuklar tarafından kullanımı incelendiğinde Dadaşkent'ten farklı bir durumla karşılaşmaktayız. Kayakyolu alt bölgesinde bazı sitelerin bahçeleri az da olsa sitelerin çocukları tarafından kullanılsa da, alan gözlemlerinin yapıldığı farklı saatlerde sokaklarda ve boş alanlarda oynayan çocuklara rastlanmamıştır. Ancak, gelir durumunun görece düşük olduğu, Yunusemre mahallesinin kuzeydeki ilk yerleşim bölgesinde hem boş alanlarda hem de sokaklarda çocukların yoğun olarak birlikte oynadıkları gözlenmiştir. Üstelik Şekil 6'de görüldüğü gibi bu sokaklar ve boş alanlar arasında birbirine geçişler de mümkündür. Çocuklar sadece birkaç sokakta oynamamakta, kendileri için oynadıkları, iletişime geçtikleri bölgeler inşa etmektedirler. Bu durum, gelir durumu ve eğitim durumu farklılıklarının çocukların kentsel mekânla ilişkisini değiştirdiğine dair ipuçları vermektedir. Ancak bu başka bir çaışmanın konusu olarak sırada beklemektedir.

Şekil 7 Yenişehir Mahallesi'nin gelişme dinamikleri ile çocuk oyun alanlarının dağılımında önemli bir ilişki olduğunu göstermektedir. Hem aktif yeşil alanların hem de bunların içindeki çocuk oyun alanlarının sıklığı planlama ve uygulama aşamalarında açık-kapalı alan dengesine özellikle dikkat edildiği, hatta artan konut yoğunluğu ile paralel bir artış sağlandığı da görülmektedir. Ancak tüm alanın erişilebilirlik açısından analizi diğer bölgelerde olduğu gibi burada da farklı yaş gruplarının temel intiyaçları üzerinden bir değerlendirme yapılmadığını göstermektedir. Özellikle yoğun kış koşullarının yaşandığı Erzurum gibi kentlerde bu gibi alanlarının aktif kullanımlarının arttırıması için çok daha sık bir şekilde planlaması gerekmektedir. Erişilebilirlik analizleri 11 yaş ve altı çocuk grupları için diğer mahallelere göre çok daha fazla fark alanı bulunmasına rağmen yine de herhangi bir parka erişim sorununun yaşandığı birçok bölge olduğunu göstermektedir. 12 yaş ve üzeri için ise sadece kuzeydeki eski gecekondu bölgesi ile halen yapılaşmakta olan bölgede ve bölgenin doğusunda kalan küçük kent parçalarında sorun yaşanmaktadır. Ancak Kayakyolu ve Dadaşkent'ten farklı olarak Yenişehir'in özellikle gecekondu önleme bölgesi olarak yapılaşan alanında sokaklar da birer oyun alanı olarak kullanılmaktadır. Yunu- 
semre Mahallesi'ndeki plansız gelişen bölgede de çocukların sokakları birer oyun mekânı olarak kullanabildikleri düşünüldüğünde çocukların kentsel mekân kulla- nımları ile ailelerinin sosyo-ekonomik durumları arasında bir ilişki olabileceği sorunsalı bir kez daha karşımıza çıkmaktadır.

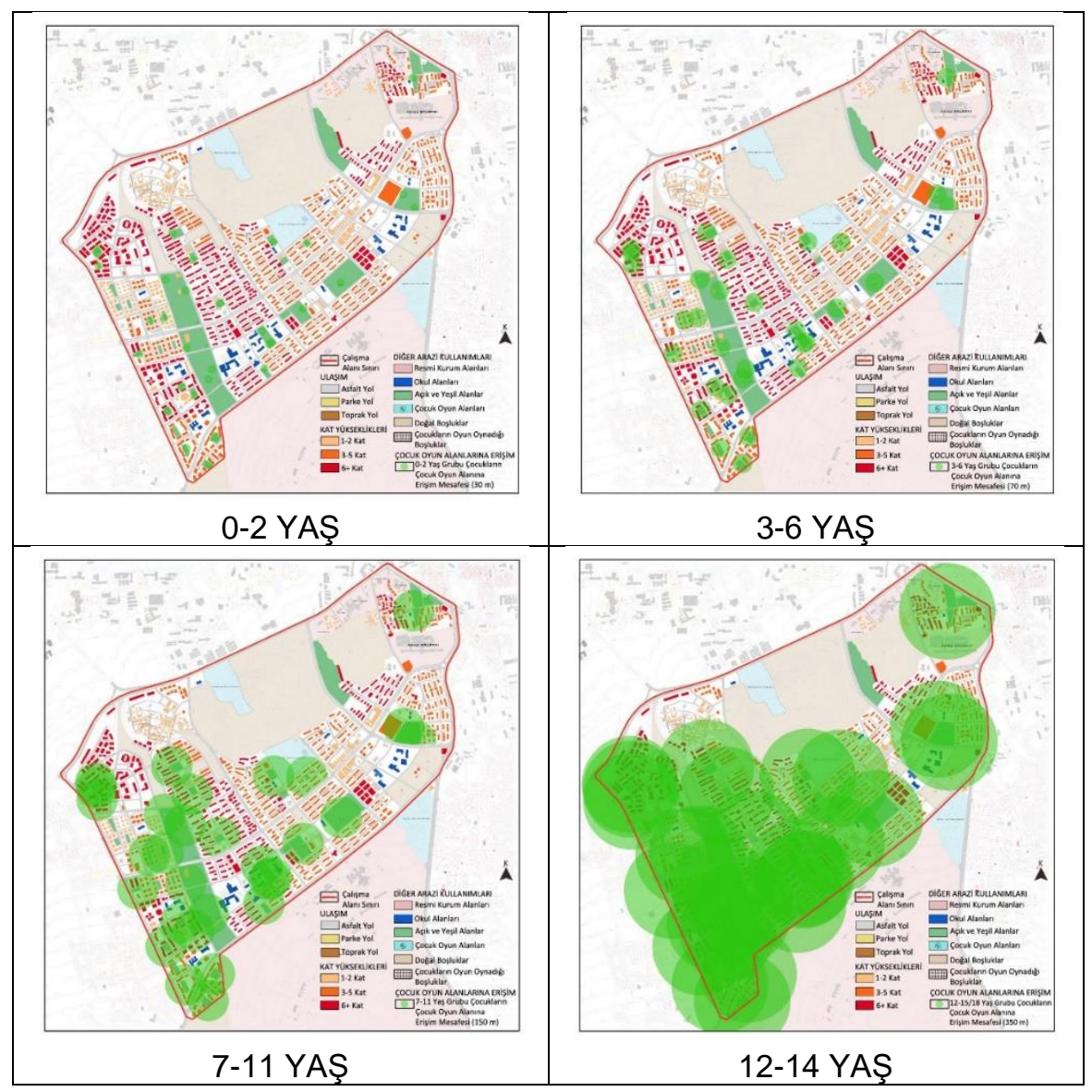

Şekil 7. Yenişehir Mahallesinde Yeşil Alanlar ile Çocuk Oyun Alanlarının Dağılımı ve Erişilebilirlik Açısından Analizi

\section{Çalışma Alanındaki Çocuk Oyun Alanlarının Yeterlilik Analizi}

Bu üç yerleşim yerindeki çocuk oyun alanlarının erişilebilirliklerine ilişkin değerlendirmenin ardından yeterliliklerine ilişkin de bir değerlendirme yapmak gerekmektedir. Tablo 4'de görüldüğü gibi ne yazık ki yerleşmelerde çocuk başına düşen oyun alanı miktarı $1 \mathrm{~m}^{2}$ 'ye dahi erişememektedir. Bununla birlikte Dadaşkent ve Yunusemre Mahallelerinde toplam açık yeşil alan miktarının da oldukça yetersiz olduğu dikkat çekmektedir. Yenişehir Mahallesi ise toplam açık yeşil alan varı̆̆ı açısından en azından imar mevzuatımızdaki standartları yakalamış bir bölgedir. Bu durum planlı olarak gelişmiş ve planların uygulanması aşamasında gerekli hassasiyetin gösterilmiş olduğu yerleşim yerlerinde kentsel yaşanabilirliği arttıracak açık yeşil alan kullanımlarının çok daha etkin kullanıldığını göstermektedir. Ancak erişilebilirlik sorunlarının görece az olduğu bölgelerde bile çocuklar için ayrılan alanların yetersizliği dikkat çekmektedir. Yeşil alan içerisindeki çocuk oyun alanı miktarı, çocuk oyun alanlarının tekil büyüklükleri ve yer seçimleri bu konuda oldukça etkili olmaktadır.

Tablo 4. Çalışma Alanlarındaki Çocuk Oyun Alanlarının Dağılımı

\begin{tabular}{|l|c|c|c|c|c|c|}
\hline & $\begin{array}{c}\text { Yeşil alan } \\
\text { Toplamı } \\
\left(\mathrm{m}^{2}\right)\end{array}$ & $\begin{array}{c}\text { Mevcut Oyun } \\
\text { Alanları Top- } \\
\text { lamı }\left(\mathrm{m}^{2}\right)\end{array}$ & Nüfus & $\begin{array}{c}\text { Mahalledeki Ço- } \\
\text { cuk Nüfusu (0- } \\
14 \text { Yaş) }\end{array}$ & $\begin{array}{c}\text { Kişi Başına Düşen } \\
\text { Yeşil Alan Miktarı } \\
\left(\mathrm{m}^{2} / \mathrm{kissi}\right)\end{array}$ & $\begin{array}{c}\text { Çocuk Başına Dü- } \\
\text { şen Çocuk Oyun } \\
\text { Alanı Miktarı }\left(\mathrm{m}^{2}\right)\end{array}$ \\
\hline Dadaşkent & 36938 & 3090 & 35653 & 5954 & 1,0 & 0,52 \\
\hline Yunusemre & 67940 & 2782 & 46419 & 8216 & 1,5 & 0,34 \\
\hline Yenişehir & 373044 & 4632 & 34318 & 6074 & 10,9 & 0,76 \\
\hline
\end{tabular}


Daha önce de belirtilen normlara göre her bir çocuk oyun alanını en az $250 \mathrm{~m}^{2}$ büyüklüğünde olmalıdır. Çalışma alanındaki oyun alanlarının büyüklükleri incelendiğinde Dadaşkent'teki oyun alanlarının ortalama $281 \mathrm{~m}^{2}$ ile diğer yerleşimlerden görece daha iyi bir durumda olduğu anlaşılmaktadır. Ancak burada da çocuk oyun alanları-

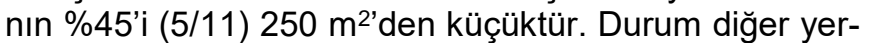
leşimler için çok daha vahimdir. Yunusemre Mahallesi'ndeki 13 parktan 9'u (\%69), Yenişehir Mahallesi'ndeki 25 parktan 21'i (\%84) 250 m²'den küçüktür (Tablo 5). Öte yandan yapılan analizler çocuk oyun alanlarının sayısal fazlalığının erişilebilirlik açısından olsa da, yeterlilik açısından olumlu etkisinin olmadığını göstermektedir. Sayısal olarak en fazla çocuk oyun alanına sahip Yenişehir mahallesindeki toplam yeşil alanların sadece binde biri çocuk oyun alanı olarak ayrılmıştır (Tablo 4). Bu oran Yunusemre Mahallesi'nde binde dörde, Dadaşkent'te ise binde 8'e çıkmaktadır. Benzer şekilde çocuk oyun alanlarının ortalama büyüklükleri düşünüldüğünde de her ne kadar hem toplam açık-yeşil alan miktarı açısından (10,9 $\left.\mathrm{m}^{2} / \mathrm{kişi}\right)$, hem de çocuk başına düşen oyun alanı miktarı açısından $\left(0,76 \mathrm{~m}^{2} /\right.$ çocuk $)$ lider bölge olsa da Yenişehir Mahallesi'ndeki oyun alanlarının verdiği hizmetin etkinliği ve kalitesi açısından oldukça yetersiz kaldığı görülmektedir.

Tablo 5. Çalışma Alanındaki Çocuk Oyun Alanlarının Dağılımı

\begin{tabular}{|c|c|c|c|c|c|c|c|}
\hline \multirow[t]{2}{*}{$\begin{array}{c}\text { Park } \\
\text { No }\end{array}$} & \multicolumn{3}{|c|}{$\begin{array}{c}\text { Çocuk Oyun Alanlarının Büyüklükleri } \\
\left(\mathrm{m}^{2}\right)\end{array}$} & \multirow[t]{2}{*}{$\begin{array}{c}\text { Park } \\
\text { No }\end{array}$} & \multicolumn{3}{|c|}{$\begin{array}{l}\text { Çocuk Oyun Alanlarının Büyüklükleri } \\
\left(\mathbf{m}^{2}\right)\end{array}$} \\
\hline & Dadaşkent & Yunusemre & Yenişehir & & Dadaşkent & Yunusemre & Yenişehir \\
\hline 1 & 519 & 97 & 125 & 14 & & & 85 \\
\hline 2 & 168 & 264 & 109 & 15 & & & 140 \\
\hline 3 & 261 & 361 & 216 & 16 & & & 86 \\
\hline 4 & 488 & 124 & 98 & 17 & & & 100 \\
\hline 5 & 95 & 234 & 453 & 18 & & & 97 \\
\hline 6 & 123 & 621 & 142 & 19 & & & 171 \\
\hline 7 & 428 & 186 & 131 & 20 & & & 33 \\
\hline 8 & 84 & 285 & 144 & 21 & & & 17 \\
\hline 9 & 289 & 150 & 98 & 22 & & & 123 \\
\hline 10 & 201 & 69 & 620 & 23 & & & 222 \\
\hline 11 & 434 & 100 & 174 & 24 & & & 100 \\
\hline 12 & & 156 & 414 & 25 & & & 614 \\
\hline 13 & & 135 & 120 & & & & \\
\hline
\end{tabular}

\begin{tabular}{|r|c|c|c|}
\hline & Dadaşkent & Yunusemre & Yenişehir \\
\hline TOPLAM $\left(\mathbf{m}^{2}\right)$ & $\mathbf{3 0 9 0}$ & $\mathbf{2 7 8 2}$ & $\mathbf{4 6 3 2}$ \\
\hline ORT $\left(\mathbf{m}^{2}\right)$ & 281 & 214 & 185 \\
\hline
\end{tabular}

Not: Renkli kutucuklar $250 \mathrm{~m}^{2}$ 'den küçük çocuk oyun alanlarını göstermektedir.

\section{Değerlendirme}

Dadaşkent, Yunusemre ve Yenişehir mahalleleri için yapılan öznel tartışmalardan sonra, bu mahallelerdeki çocuk oyun alanlarının dağılımını ve farklı yaş grupları açısından erişilebilirliklerini karşılaştırmalı bir şekilde analiz etmek yerinde olacaktır. Şekil 8'de parklara (yeşil) erişilebilirliğin en yoğun olduğu bölgeler ten rengi, erişilebilirliğin en zayıf olduğu bölgeler ise kırmızı renk ile gösterilmiştir. Buna göre her üç mahallede de hiç park alanı olmayan bölgeler olduğu gibi, erişimin oldukça zayıf olduğu birçok bölgenin varlığı da dikkat çekmektedir. Buna göre üç mahallede de kentsel gelişim dinamikleri çerçevesinde farklı alt bölgeler oluşmuş ve açık-yeşil alan ile çocuk oyun alanı varlığı da buna bağlı olarak değişmiştir. İncelediğimiz üç kentsel yerleşim bölgesinde de çocuk oyun alanlarının yer seçimleri, yoğunlukları ve hatta varlıkları mevcut kentsel dokunun gelişim süreçlerinden birebir etkilenmiştir. Planlı gelişimin hâkim olduğu dönemlerde çocuk oyun alanlarının inşasına daha hassasiyetle yaklaşıldığı da görülmektedir. Bu durum kentsel gelişim dinamiklerinin kentsel mekân ve bu mekândaki iliş̧ilerin biçimlenmesinde oldukça etkili olduğunu göstermektedir. 
Şekil 8'de görüldüğü gibi mahallelerdeki parkların yer seçimleri 11 yaş ve altı gruplar için erişilebilirlik açısından olumsuzluklar içermektedir. Bu yaş grubu en fazla sarı renk ile gösterilen bölgede hareket edebilmektedir. Dolayısı ile onlar için yerleşimlerin büyük bir kısmında erişilebilir uzaklıkta bir çocuk oyun alanı bulunmamaktadır. Bununla birlikte 12-14 yaş arası çocuklar açısından kentsel mekânın ve çocuk oyun alanlarının birçok seçenek sunduğu görülmektedir (turuncu renkli bölge - 350 m yürüyüş mesafesi). Şekil 8'ye göre parkların varlığı ve erişilebilirlikleri açısından sorunun en büyük olduğu kentsel parçaların 1960 sonrasında gecekondu yoluyla gelişen bölgeler ile 2000 sonrasındaki inşaat odaklı kalkınma dinamiğinin tetiklediği gelişme bölgeleri olduğu görülmektedir.

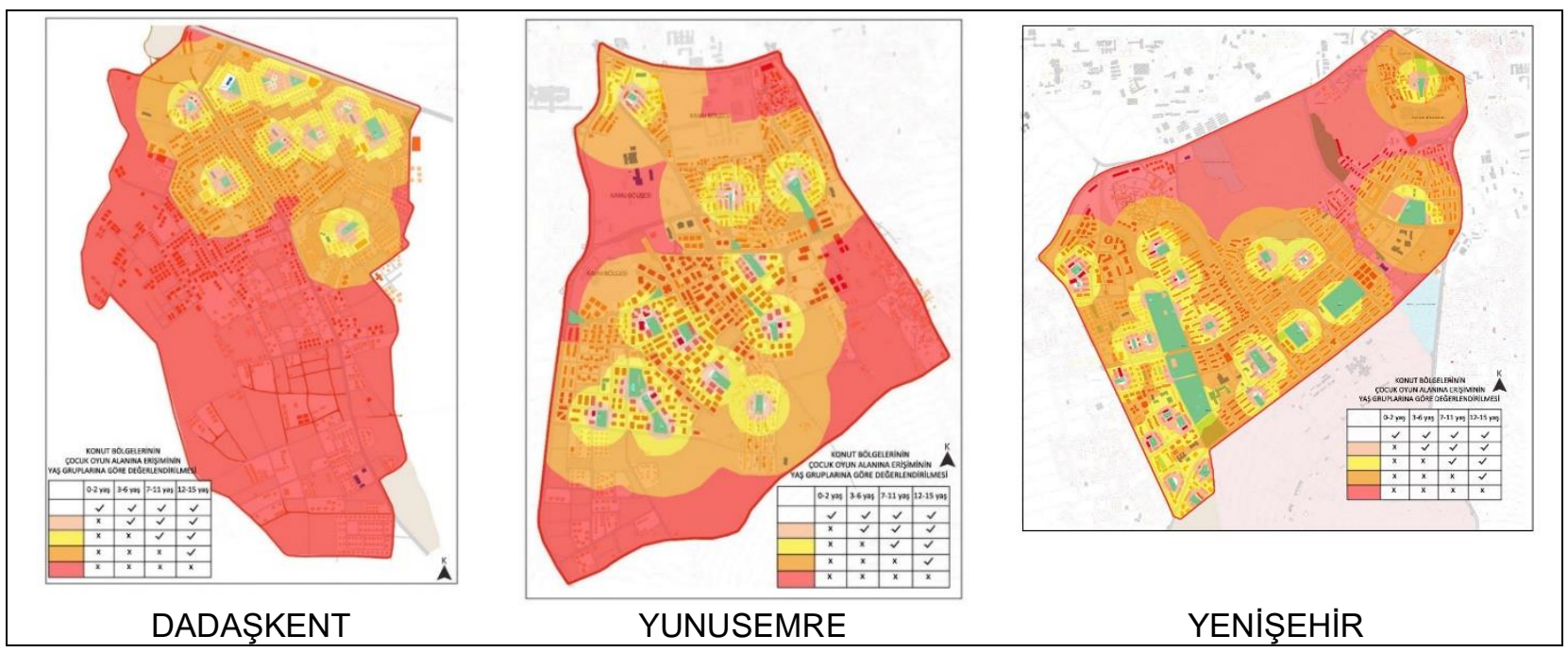

Şekil 8. Çalışma alanlarındaki çocuk oyun alanlarının karşılaştırmalı erişilebilirlik analizi

Yunusemre mahallesinin kuzeyinde parklar oldukça yetersizken, güneyindeki Kayakyolu alt bölgesinde yeşil alanlar kendi aralarında belirli bir sistem oluşturmuşlardır. Benzer şekilde Dadaşkent'in kuzey bölgesinde de park alanlarının sistemli bir biçimde yer seçtikleri görülmektedir. Ancak erişilebilirlik mesafeleri 350m'ye çıkan 12-14 yaş grubu için bile Dadaşkent'teki parkların yetersizlikleri oldukça dikkat çekmektedir. Mahallede güneye gidildikçe park sayı ve yoğunluklarının azaldığı, aynı zamanda ciddi erişilebilirlik sorunları olduğu söylenebilir. Bu sorunların yaşandığı bölgenin yerleşimin 2010 sonrası gelişen bölgesi olması da oldukça manidardır. Bu dönem tüm ülkeyi saran inşaat odaklı kalkınma stratejisinin de bir uzantısı olarak konut inşa hızına ne yazık ki özellikle sosyal altyapıların yapım hızı yetişememekte ve kentlerin özellikle yeni yapılaşan alanları bu gibi açık yeşil alan benzeri kentsel-sosyal altyapı konularında eksik kalmaktadır. Ne yazık ki bu durum hem kentlileşme dinamiklerini hem de toplumsal gelişimi oldukça olumsuz etkilemektedir. 1980'lerin sosyal konut duyarlı kooperatifleşme yoluyla kentleşen bölgesi olarak öne çıkan Yenişehir bölgesinde ise toplam açık-yeşil alan miktarı diğer iki bölgenin tam tersine oldukça fazladır. Bu durum yerel yönetimler tarafından gerekli hassasiyet gösterildiğinde kentsel-sosyal donatıların plana uygun olarak gerçekleştirilebilmesinin olumlu sonuçlarını açıkça önümüze sermektedir. Ancak yapılan analizler tüm bu yeşil alanlar içerisinde çocuk oyun alanlarına ayrılan miktarın oldukça az ve yetersiz olduğunu göstermektedir. Bu durum ne yazık ki imar mevzuatımızın bu konudaki eksikliğinden kaynaklanmaktadır. Mevzuat sadece kent içinde aktif-yeşil alan için ayrılması gereken en az alan büyüklüğü konusunda bir standart sunarken, bu alanların kullanımına dair yönlendirici bir detay içermemektedir. Bu nedenle birçok kentte açık-yeşil alanların konut alanları içerisindeki dağılımı bile göz ardı edilip kentteki toplam yeşil alan miktarı hesaplanmaktadır. Oysa bu analizler de göstermektedir ki hem genel olarak açık yeşil alanların etkin dağılımının sağlanması, hem de çocuk oyun alanları gibi özel kullanımların etkin ve verimli bir şekilde gerçekleştirilebilmesi için imar mevzuatımızın bu hassasiyetle yeniden ele alınması gerekmektedir.

Yerinde yapılan gözlem ve analizlerde Erzurum'daki çocuk parklarının genel tasarım ilkesi olarak ailelerle gidilebilecek şekilde açık yeşil alanlarla birlikte tasarlandığı anlaşılmıştır. Buna rağmen bu alanların yaz aylarında dahi aileler ve çocuklar tarafından etkin bir şekilde kullanılmadığı gözlenmiştir. Bu nedenle çocukların belirlenen bu çocuk oyun alanları dışında hangi kentsel mekânları oyun alanı olarak kullandığı da araştırmaya dâhil edilmiştir. Bu araştırma karşımıza ilginç bir sonuç ortaya çıkarmıştır. Buna göre çocukların çocuk oyun alanları dı- 
Şındaki alanları (sokaklar ve diğer kentsel boşluklar) kullanımı bölgenin sosyo-ekonomik durumuna göre değişmektedir. Yaşayanların sosyo-ekonomik durumlarının görece yüksek olduğunu bildiğimiz bölgelerde (Dadaşkent, Kayakyolu ve Yıldızkent Bölgeleri) çocuklar aileleri eşliğinde sadece kendilerine ayrılan çocuk oyun alanlarında oynarken, yaşayanların sosyo-ekonomik durumlarının görece düşük olduğunu bildiğimiz bölgelerde (Yunusemre mahallesinin kuzey bölgesi ile Yenişehir Mahallesi'nin çekirdek bölgesi) çocukların sokakları ve bazı boş alanları da bir oyun mekânı olarak kullandıkları gözlenmiştir. Hatta özellikle Yunusemre mahallesinin kuzey bölgesinde bu sokak ve boş alanlar arasındaki geçişlerle büyüyen oyun bölgeleri oluşturulduğu, bunun mahalle yaşamının kendi dinamikleri içinde gerçekleştiği görülmektedir. Ancak bu varsayım anket ve benzeri yöntemleri de içeren daha detaylı çalışmalarla desteklenmesi gereken bir olgudur.

Bu çalışma çerçevesinde söz konusu yerleşim bölgelerindeki parkların alan büyüklükleri açısından yeterlilikleri de sorgulanmıştır. Erişilebilirlik açısından en olumlu sonuç veren Yenişehir bölgesi ne yazık ki sayı açısından yüksek bir değere sahip olmasına rağmen, gerek ortalama park büyüklüğü gerek parkların oldukça büyük bir

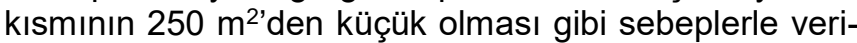
len hizmetin değeri açısından oldukça yetersiz bir durumdadır. Tüm bölgelerde çocuk başına düşen oyun alanı miktarı $1 \mathrm{~m}^{2}$ 'nin altındadır. Bu durum daha önce de vurgulandığı gibi çocuk oyun alanları konusunda ne toplumumuzda ne de yasal mevzuatımızda yeterli bir hassasiyetin henüz oluşmadığını göstermektedir. Öncelikle yasal mevzuatımızda çocuk oyun alanlarının büyüklüğü ve kentsel alan içindeki dağılımına ilişkin bir standart belirlenmeli ve çocuk oyun alanları konusunda bazı zorunluluklar tanımlanmalıdır.

\section{SONUÇLAR}

Kentsel mekânın kullanımı çocukların gelişimi açısından ve dolayısı ile toplumsal gelişim açısından oldukça önemlidir. Bu nedenle sürdürülebilir kentsel gelişme ve toplumsal kalkınmanın sağlanmasının önemli ayaklarından biri kentsel mekânda çocukların intiyaçlarına cevap verebilecek düzenlemeler yapılmasıdır. Bu makalede çocuk ve kentsel mekân ilişkisini incelemek için Erzurum'da kentsel gelişme dinamikleri farklılık gösteren $\mathrm{Da}$ daşkent, Yunusemre ve Yenişehir mahallerinde, çocukların oyun alanları üzerine karşılaştırmalı bir analiz gerçekleştirilmiştir.

Bu çalışma her ne kadar belirlenen bölgelerdeki açık yeşil alanların erişilebilirlikleri ve alan büyüklükleri açısından yeterliliklerini sorgulasa da, sonraki çalışmalar için de önemli ipuçları vermektedir. Karşımıza önemli bir iki- lem çıkmaktadır. Çocukların kentsel mekân kullanımlarını destekleyen ve çocukların kentsel mekân kullanımlarını belirleyen şey planlı bir gelişme ile bu hizmetlerin etkin ve verimli sunumu mu, yoksa ailelerin sosyo ekonomik durumları mıdır? Gelecekte bu konuda yapılacak çalışmaların çocukların kentsel mekânı kullanımını etkileyen dinamikleri araştırmaları gerekmektedir. Bunun için öncelikle mevcut çocuk oyun alanlarının farklı yaş gruplarınca aktif kullanım durumları ile bu alanların mekânsal nitelikleri arasındaki ilişki incelenmelidir. Diğer yandan bölge halkının sosyo-ekonomik durumlarının çocukların kentsel mekân kullanımlarına (sokak ve diğer boş alanları da içerecek şekilde) etkisini sorgulayan yeni analizler yapılmalıdır. Bununla birlikte Erzurum gibi kış kentlerinde kış koşullarında bu alanların aktif kullanımını sağlayacak dinamikler de araştırmanın bir parçası haline getirilmelidir. Çünkü araştırma göstermektedir ki, $350 \mathrm{~m}$ 'lik erişilebilirlik mesafesinde bile farklı yaş gruplarının mekân kullanımları kısıtlanmakta, bu durum özellikle kış koşullarında kentsel mekân kullanımı konusunda daha büyük sıkıntılar doğurmaktadır. Dolayısı ile özellikle yoğun yapılaşmış bölgelerde, kış koşullarının da düşünülmesiyle, sokakların ve diğer boş alanların çocukların kullanımını destekleyecek şekilde yeniden tasarımına ilişkin alternatifler aranmalıdır.

Tüm bunların ötesinde, bir kamusal hizmet sunumu olan çocuk oyun alanlarının farklılaşan kentsel gelişme dinamiklerinden olabildiğince az etkilenmesi sağlanmalıdır. Mevzuatımızda yerel yönetimleri çocuk oyun alanlarının yapımı ile ilgili yönlendiren bir zorunluluk bulunmaması bu hizmetin sunumunu değişen koşullara bağımlı hale getirmiştir. Bu nedenle acilen çocuk oyun alanlarının büyüklüğü ve yer seçimleri ile ilgili temel standartlar geliştirilerek imar mevzuatının bir parçası haline getirilmelidir. Böylece ülkemizde devam eden kentsel dönüşüm projeleri ile devam eden kentsel mekânların yenilenmesi süreci oluşturulacak yeni kentsel yaşam alanlarının daha çocuk dostu olması için de bir fırsata dönüştürülebilecektir.

\section{TEŞEKKÜR}

Arazi kullanımı güncellemesi ve haritalama çalışmaları sırasında yaptıkları katkılardan dolayı Atatürk Üniversitesi, Şehir ve Bölge Planlama Bölümü öğrencilerinden M. Emirhan Karaman ile Muhammed Ayık'a teşekkür ederiz.

\section{KAYNAKLAR}

Akarsu, F. (1984). Piaget'ye Göre Çocukta Mekân Kavramının Gelişimi. Mimarlık (9): 31-33.

Atkinson, R. L., Atkinson, R. C., Smith, E. E., Bem, D. J., Nolenhoeksema, S. (2006). Psikolojiye Giriş. Ankara: Arkadaş Kitabevi. 
Bakan, K., Konuk, G. (1987). Türkiye'de Kentsel Dış Mekânların Düzenlenmesi. Ankara: TÜBITAK Yapı Araştırma Enstitüsü.

Birol, G. (2009). Çocuk Dostu Kent Neresidir? Megaron Balıkesir, Mimarlar Odası Balıkesir Şubesi Dergisi, 10-13.

Churchman, A. (2003). Is There a Place for Children in the City? Journal of Urban Design, 8(2): 99-111.

Corsi, M. (2002). The Child Friendly Cities Initiative in Italy. Environment and Urbanization, 14(2): 169-179.

Dursun, D. (2015a). Emlak Geliştirme Sektöründeki Yeniden Yapılanmanın Kentsel Süreçlere Etkisi: Erzurum ve Kayseri Örnekleri. ODTÜ Kentsel Politika Planlaması ve Yerel Yönetimler Anabilim Dalı, Yayımlanmamış Doktora Tezi.

Dursun, D. (2015b). Capacity for Urban Adaptation to Climate Change: Case Study of Erzurum and Kayseri. ICUC9 - 9th International Conference on Urban Climate jointly with 12th Symposium on the Urban Environment. Toulouse, France.

Dursun, D., Yavaş, M. (2015). Climate-Sensitive Urban Design in Cold Climate Zone: The City of Erzurum, Turkey. International Review for Spatial Planning and Sustainable Development, $\quad 3(1)$ : 17-38. doi:http://dx.doi.org/10.14246/irspsd.3.1_17

Dursun, D., Yılmaz, S., Yılmaz, H., Irmak, A., Demir, M., Yavaş, M. (2015). Hava Kirliliğinde Ekolojik Koridor Senaryoları: Erzurum Kenti. Erzurum: Rana Medya.

Duygu Çukur, E. G. (2011). Erken Çocukluk Döneminde Görsel Algı Gelişimine Uygun Mekân Tasarımı. Aile ve Toplum, 7(24): 25-36.

Erbil, F. (2016). Çocuk Algısı ve Çocuk Katılımı. G. V. Ayhan Kaya içinde, Değerler Eğitimi: Eğitimde Farklılık ve Katılım Hakkı (s. 107-126). İstanbul: İstanbul bilgi Üniversitesi Yayınları.

Ermiyagil, M. S., Gürçınar, C. S. (2015). Kentsel Mekânın Gelişiminde Çocuk Oyun Alanlarının Rolü: K.K.T.C'de Yeni Kent Gönyeli Örneği. İdeal Kent: Çocuk ve Kent, 17: 12-45.

Ersoy, M. (2015). Kent Planlamada Standartlar. İstanbul: Ninova Yayınevi.

Ersoy, M. (2017). Osmanlı'dan Günümüze İmar ve Yasalar. İstanbul: Ninova Yayınları.

Gökmen, H. (2008). Çocuk Dostu Kent. 1. Çocuk, Kent ve Mimarlık Ulusal Buluşması, 21-22. Ankara: TMMOB Mimarlar Odası Ankara Şubesi.

Günay, N. (2016). Fiziksel Çevrelerin Çocuk Üzerindeki Etkisi Bağlamında 'Kapsayıcı Oyun Alanları'. İstanbul: Yıldız Teknik Üniversitesi, Mimari Tasarım Programı, Yüksek Lisans Tezi.

James, A. (2001). Yeni Çocuk Sosyolojisinde Sorunlar, Bakış Açıları ve Uygulamalar. B. Onur (Dü.), Dünyada ve
Türkiye'de Değişen Çocukluk: III. Ulusal Çocuk Kültürü Kongresi Bildirileri 16-18 Ekim 2000 içinde, 27-36. Ankara: Ankara Üniversitesi- Çocuk Kültürü Araştırma ve Uygulama Merkezi Yayınları No:9.

James, A. (2010). Interdisciplinarity - for better or worse. Children's Geographies, 8(2): 215-216. doi:10.1080/14733281003691475

James, A. ve Prout, A. (1997). Constructing and Resconstructing Childhood. NewYork: Routledge.

Koç, N., Tavşancıl, E., Demir, E. (2015). Çocuk Dostu Şehir Girişimi ve Çocukların Gözüyle Ankara. İdeal Kent - Çocuk ve Kent, 17: 106-139.

Köse, O. (2016). Geçmişten Günümüze Şehir ve Çocuk - Cilt I. Samsun: Canik Belediyesi Kültür Yayınları.

Özdemir, N. (2014). Osmanlı'dan Cumhuriyete Bir Cemiyet Kadını: Nakiye Elgün. Phoenix .

Severcan, Y. C. (2015). Çocukların Gözünden Çocuk Dostu Yer Kavramı ve Yaşanılan Çevrelerin Değerlendirilmesi: İstanbul Örneği. İdeal Kent: Çocuk ve Kent, 17:140-181.

Şişman, E., Özyavuz, M. (2010). Çocuk Oyun Alanlarının Dağıımı ve Kullanım Yeterliliği: Tekirdağ Örneği. Tekirdağ Ziraat Fakültesi Dergisi, 7(1): 13-22.

Tandoğan, O. (2014). Çocuk İçin Daha Yaşanılır Bir Kentsel Mekân: Dünyada Gerçekleştirilen Uygulamalar. Megaron, 9(1): 19-33. doi: 10.5505/MEGARON.2014.43534

Taşçı, B. G. (2010). Sokağın Günümüz Koşullarında Çocuk Oyun alanı Olarak Ele Alınması ve Değerlendirilmesi. İmir: Dokuz Eylül Üniversitesi, Mimarlık Bölümü, Yüksek Lisans Tezi.

URL-1 (2019). UNICEF - Çocuk Dostu Kentler Girişimi, https://childfriendlycities.org/ (Erişim Tarihi: 08.02.2019)

URL-2 (2014). Mekânsal Planlar Yapım Yönetmeliği, http://www.mevzuat.gov.tr/Metin.Aspx?Mevzuat$\mathrm{Kod}=7.5 .19788 \&$ Mevzuatlliski=0\&sourceXmISearch=mekânsal (Erişim Tarihi: 08.02.2019)

Uysal, A. (2015). Çocuk Coğrafyaları ve Çocukların Gündelik Mekânları. İdeal Kent - Çocuk ve Kent, 17: 46-61.

Uzun, G. (1990). Kentsel Rekreasyon Alan Planlaması. Adana: Çukurova Üniversitesi Ziraat Fakültesi Ders Kitabı No:48.

Ünal, M. (2009). Çocuk Gelişiminde Oyun Alanlarının Yeri ve Önemi. İnönü Üniversitesi Eğitim Fakültesi Dergisi, 10(2): 95-109.

Yalçınkaya, Ş. (2015). Modern Kentin Yeni Kamusal Alanında Çocuk, Alışveriş Merkezleri ve Serbest Zman Etkinlikleri. İdeal Kent - Çocuk ve Kent, 17: 80-105.

Yılmaz, S., Bulut, Z. (2002). Kentsel Mekânlarda Çocuk Oyun Alanları Planlama ve Tasarım İlkeleri. Atatürk Üniversitesi Ziraat Fakültesi Dergisi, 33(3): 345-351. 